\title{
THE MOTIVATION OF THE CHINESE POST-90S GENERATION FOR TRAVELLING ABROAD
}

BY

\section{SHERRY CAO}

A thesis submitted to the Victoria University of Wellington in partial fulfilment of the requirement for the degree of Master of Commerce

Victoria University of Wellington

(2019) 


\begin{abstract}
There is well-documented research on tourism motivation in tourism literature. But till now, there is limited research of tourist motivation on Chinese youth travel group, who is so-called the Chinese post-90s generation. They are unique compared to other generations in China and has gradually been a group that received great public attention. Their thoughts and behaviours are bearing the brand of the Chinese era and also showing the characteristics of the modern Chinese generation. Therefore, this study based on the Chinese social background investigates Chinese youth tourists' motivation for travelling abroad, focusing on the Chinese post-90s generation. In this study, a questionnaire survey was conducted among Chinese post-90s generation who came from major cities in China and had at least one or more overseas experiences. The research finds that the important motivational factors influencing the Chinese post-90s generation's overseas travel include: self-development and relationship; novelty; escape and relaxation. Besides, this research finds that social variables which reflect China's social changes have significant impacts on the Chinese youth tourists' overseas travel motivation. These findings not only complement the deficiencies of the existing research on the tourist motivation of Chinese travellers but also provide important reference about Chinese youth tourism for tourism marketers and stakeholders who will deal with this potential tourism market.
\end{abstract}

Keywords: Tourist motivation; youth tourism; Chinese post-90s generation; social change 


\section{Acknowledgement}

I would like first to thank my thesis supervisor Dr Eerang Park of Tourism

Management at Victoria University of Wellington, for her comments, suggestions and efforts during my whole writing period. Also, I would like to thank those having participated in my survey, shared their precious time to fill in the questionnaire, helped collect data, and made outstanding contributions to my thesis. In addition, my thanks go to all my family members and friends for their encouragement and support. Finally, thanks again to my supervisor, family and friends who helped me throughout the process. 


\section{Table of c ontents}

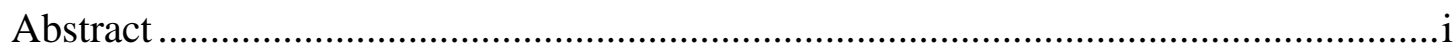

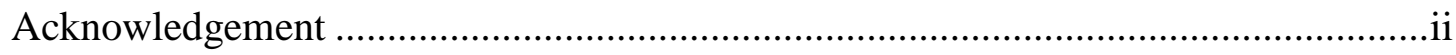

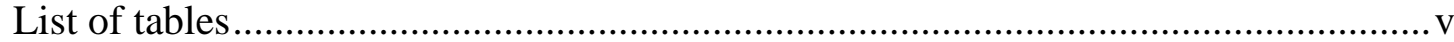

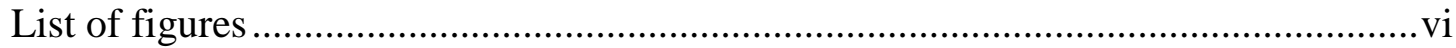

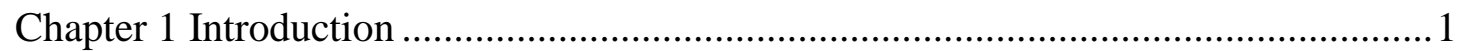

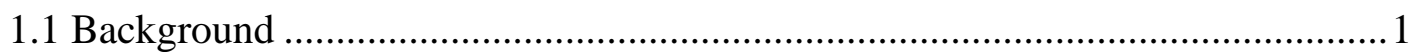

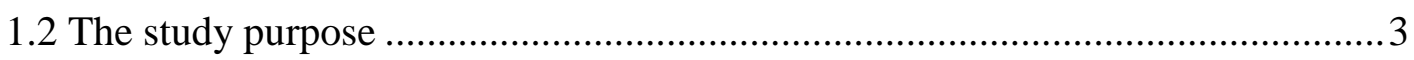

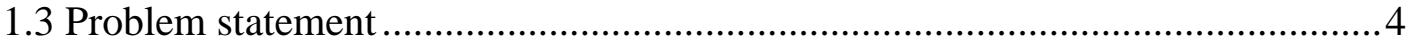

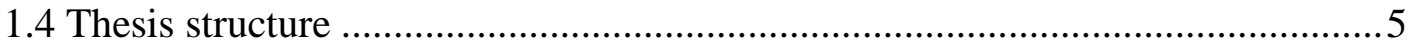

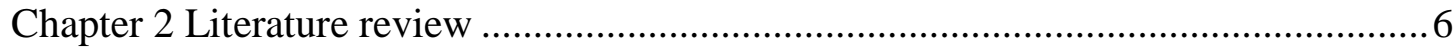

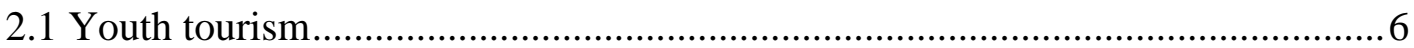

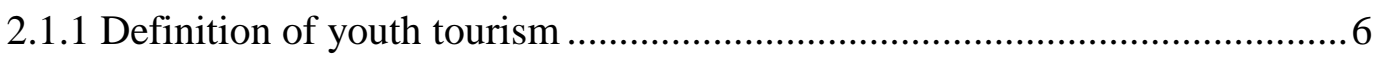

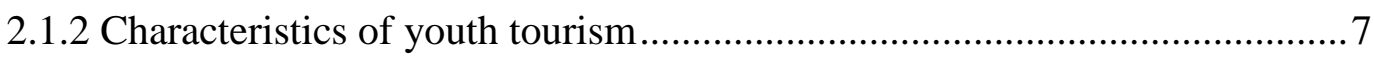

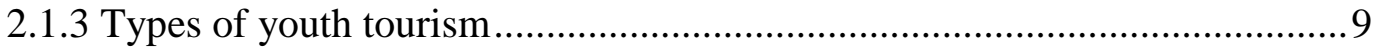

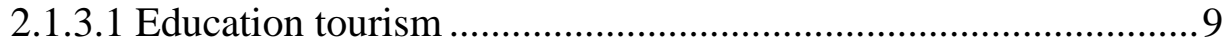

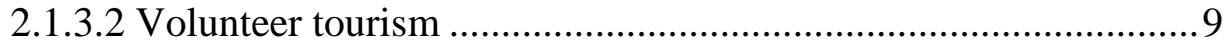

2.1.3.3 Work and travel programmes............................................... 10

2.1.3.4 Cultural exchange …............................................................ 11

2.1.3.5 Sports and adventure tourism............................................. 11

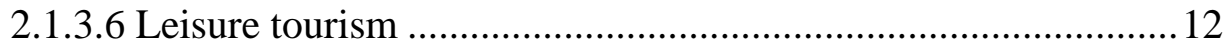

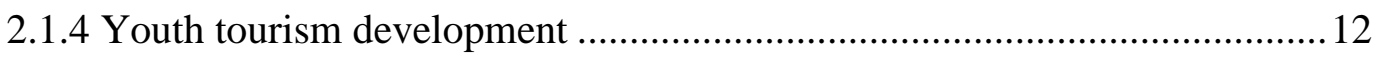

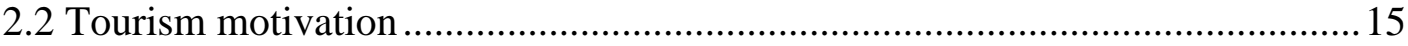

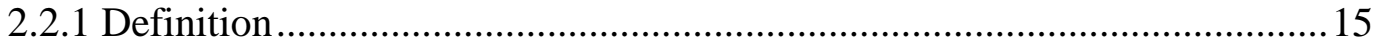

2.2.2 Theoretical approaches to tourism motivation ........................................... 16

2.2.3 Empirical studies of tourism motivation ....................................................2 21

2.2.3.1 Review of empirical findings of tourism motivation ................21

2.2.3.2 Review of empirical findings of youth tourists' motivation ......22

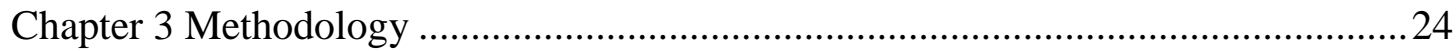

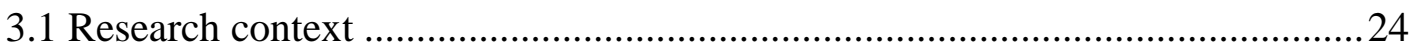

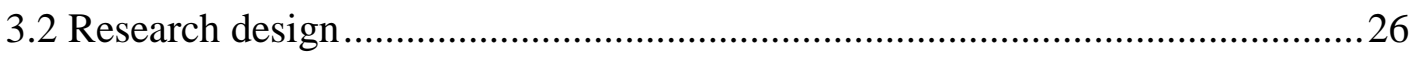

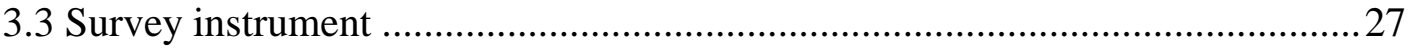




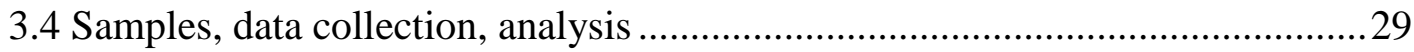

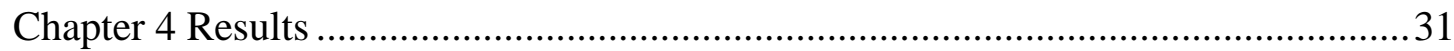

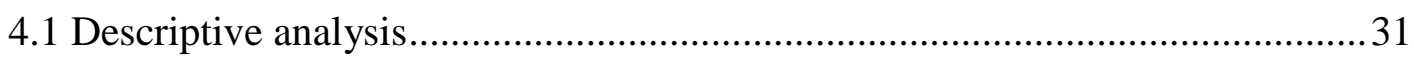

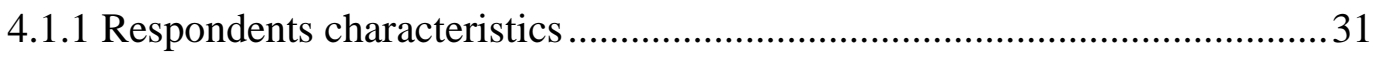

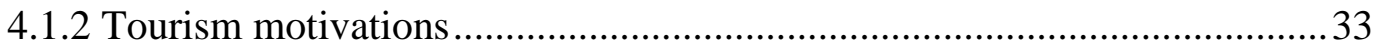

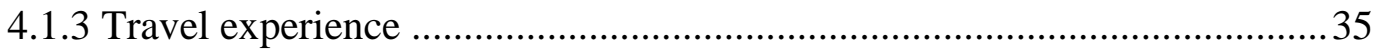

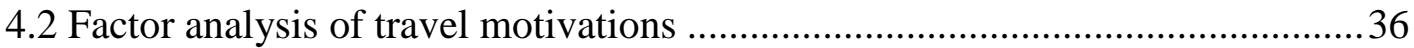

4.3 Relationship between tourism motivation and social variables ......................... 38

4.3.1 The relationship between the influence of Chinese One-child policy and Chinese post 90s generation's travelling abroad ................................................. 38

4.3.2 The relationship between media and the post-90s generation's travelling

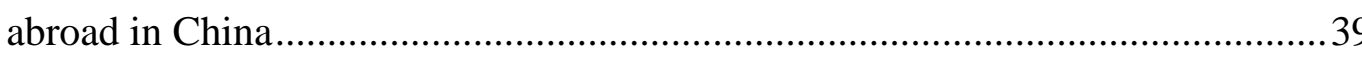

4.3.3 The relationship between education level and the motivation of the Chinese post-90s generation for travelling abroad ........................................................ 40

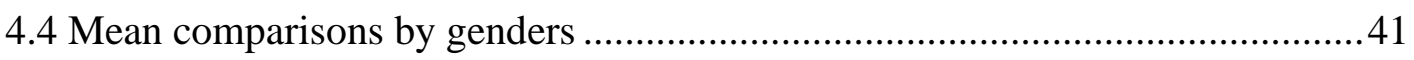

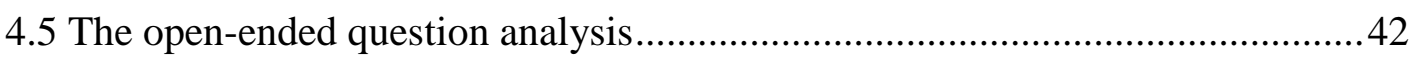

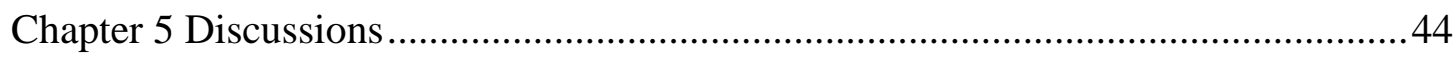

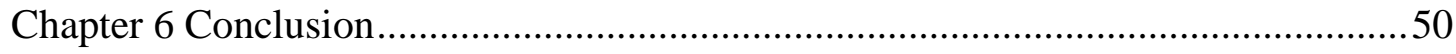

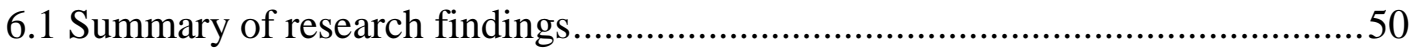

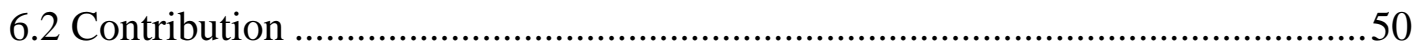

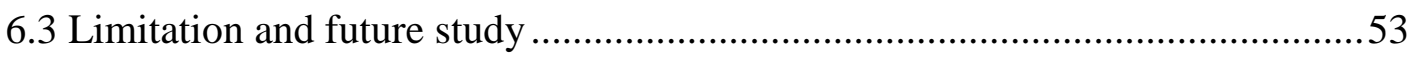

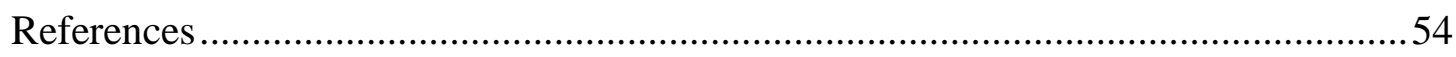

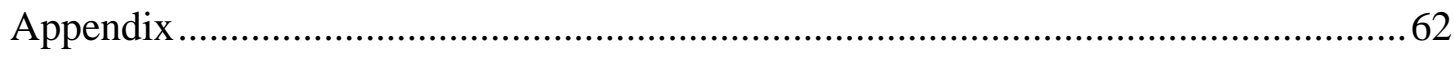

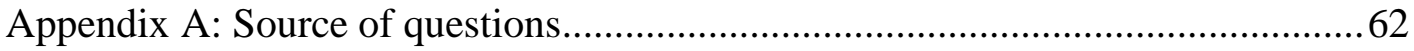

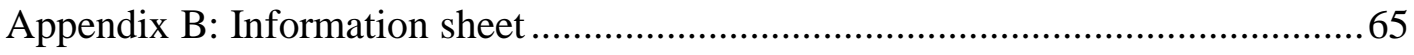

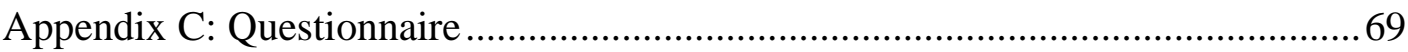




\section{List of tables}

Table 4.1 Summary of demographics characteristic...........................................32

Table 4.2 Descriptive analysis result of tourist motivations ................................34

Table 4.3 Descriptive analysis result of travel experience ...................................35

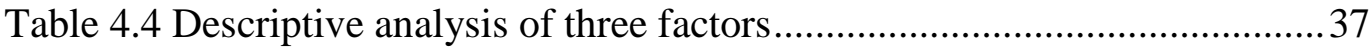

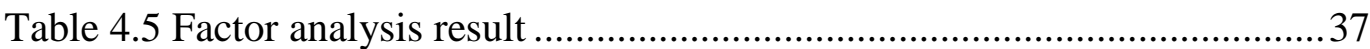

Table 4.6 Correlations of tourist motivation with only child, social media and

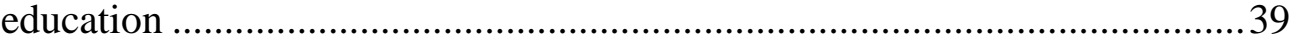

Table 4.7 One-way ANOVA and post-hoc result: Education level and

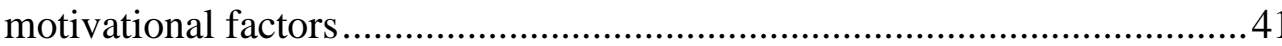

Table 4.8 T-test result: Differences between men and women ...........................42 


\section{List of figures}

Figure 4. 1 The main cities of China .... 


\section{Chapter 1 Introduction}

\subsection{Background}

China is the world's most populous country with a population of more than 1.4 billion. It is also the world's largest tourist source country. Even if the Chinese are classified according to different divisions, such as regions or ages, the number of tourists in each category is still quite large (Cvetković \& Sara, 2018). With the rapid development of China's economy, its tourism industry also gets developed. The number of outbound tourists in China and the amount of tourism consumption continue to grow as well. In 2016, the total consumption exceeded 100 billion US dollars. Outbound tourism in China as a relatively new phenomenon experiences rapid development. It is undeniable that Chinese tourists have quickly become the main force in the overseas tourism market. With the continuous development of China's tourism industry, there will be more and more people travelling in the future (Cvetković \& Sara, 2018).

Over the past three years, tourism consumption has accounted for more than $14 \%$ of the total in China's national economy. In terms of the total tourism consumption, the post-80s generation (people born between 1980 and 1989) as a whole spent the most on tourism in 2017, followed by the post-90s generation (people born between 1990 and 1999) and the post-70s generation (Surging News, 2018). What is slightly surprising is that the group with the highest consumption per capita was the post-90s generation, reaching the local currency 3515 RMB (USD 508), more than 3114 RMB (USD 450) for the post-80s generation and 3355 RMB (USD 486) for the post-70s generation. It can be seen that the post-90s generation now are more willing to spend money on travel (Surging News, 2018).

Generation Z, known in China as the post-90s generation, means the generation born after 1990. They were born and raised at a time very different from most of the age groups studied, in particular, considering the context of China's economic, social, and cultural changes and development. "Post-90s" is a derivative of "post-80s", referring to the generation of Chinese citizens born from January 1, 1990 to December 31, 1999, and all Chinese citizens born between 1990 and 2000 in some cases (Surging News, 2018). The post-90s generation in China was born in an era when China's reform and 
opening-up brought about great changes and achieved remarkable results, and information technology underwent rapid development. Therefore, in this information age, the post-90s generation is one of the first generations to enjoy and experience the achievements. In the era that the post-90s generation was born, China witnessed remarkable development and changes in all aspects of society, especially in economy, policies, culture and education.

In October 1992, the 14th National Congress of the Communist Party of China (CPC) announced that the most distinctive feature of the new era was the reform and opening up, and China's reform entered a new period (Shuguang, 2017). The reform began from China's economic system. China changed from a highly centralized planned economy to a dynamic socialist market economy; and because of this change, China's economy began to integrate with the international market and developed rapidly. Since the 1990s, with the development and growth of the non-state-owned economy, China's institutional transformation has entered a new stage. Decentralization of the public ownership economy can only describe one aspect, instead of the whole picture. The most important changes are the property right structure and the market environment. From the perspective of the property right structure, the reform has interrupted and changed the pattern of nationalization and the single development of China's economy, and initiated the road of allowing and encouraging the development of the non-state-owned economy (Shuguang, 2017). The opening up since 1980 has broken the pattern of closed operation, promoted the development of China's economy and initiated the process of internationalization. The financial sector was liberalised in the 1990s. China's entry into the World Trade Organisation liberalised its service sector, allowing foreign investment and lifting the restrictions on retail, wholesale and distribution. Financial services, banking, telecommunications and insurance were also open to foreign investment. Thus, the living standards of Chinese have been continuously improved. In the past, most people could only afford foods and housing; but now, they begin to pursue spiritual life when they are satisfied with material life.

In general, in the 1990s, a series of reform measures initiated by Chinese leaders had a profound impact on China, resulting in great changes in the economic, political and cultural aspects of the Chinese society. The impact of the changes is also fully reflected in China's post-90s generation. 


\subsection{The study purpose}

The post-90s generation in China accounts for 15.4 percent of the country's total population, reaching over 200 million, 29.5 percent of whom are over the age of 15 . According to the United Nations, by 2050, China's post-90s population will account for 31.3 percent and become the driving force of China's future development and consumption (CIW, 2015). At the same time, the Chinese tourists spent 40 percent more on travel in 2017 than the previous year, with nearly two-thirds planning to spend more on travel in the next 12 months. Among them, the post-90s generation played a big role in promoting this consumption (CIW, 2015). This group spent 80 percent more on travel than they did the year before, and also spent a significantly higher proportion of their income on tourism than other age groups (CIW, 2015). It is clear that the post-90s generation as a very important consumer group of the tourist market has become an important content that not only benefits the youth tourism market but also needs the attention from the stakeholders of the tourism market. Only by well understanding this special consumer group can the market better cater to its consumption needs.

The generational cohort theory (Inglehart, 1977) believes that the attitudes, behaviours, ideas and values of the same generation are influenced by similar social and economic backgrounds. It can also be seen clearly that the great changes in Chinese society during the birth and growth period of the generation have a significant impact on the formation of these unique attitudes and behaviour patterns. Thus, during the study on the tourism motivation of China's post-90s generation, the social changes that have greatly influenced this generation should be considered.

As China's post-90s generation plays an important role in the global tourism market, it is necessary to study further and fill the research gap in Chinese youth tourism research and offer the youth tourism market more specific information about this special Chinese youth. The purpose of this research is to find out what factors influence the motivation of the post-90s generation in China for travelling abroad, based on Chinese social changes; to identify the most important factors that affect youth tourism motivation; to explore the relationship between motivational factors and social variables. 
In summary, this study addresses the importance of the changes in Chinese society, in order to figure out the factors affecting and reflecting the travel motivations of China's post-90s generation. There are several sub-questions followed by the main research questions:

1. What are the motivations of the post-90s generation for travelling abroad?

2. Is there a significant relationship between the Chinese One-child policy and the motivations of the post-90s generation for travelling abroad?

3. Is there a significant relationship between the influence of Chinese media and the motivations of the post-90s generation for travelling abroad?

4. Is there a relationship between the education level and the motivations of the post-90s generation for travelling abroad?

\subsection{Problem statement}

In recent years, there is an upward trend of young people travelling around the world. The post-90s generation, as a new group in the tourism market, is growing and becoming a consumer group that cannot be ignored, with huge potential and development space. Tourism motivation based on tourist characteristics has been widely studied in the west. However, there are relatively few studies targeting China's post-90s generation, despite the huge potential. Also, in the academic field of China, there are few studies on youth tourism, which are limited to the general tourism market. This can be a big gap in the research on China's tourism. Even though the concept and research of youth tourism around the world become more mature, the majority is from the west. However, the research on tourism in the Chinese context is limited to the general tourism market. Meanwhile, Sofield and Li (2007) point out that there are differences between Chinese and western tourists (Sofield \& Li, 2007). Due to the huge differences in social and demographic backgrounds, the research results in the western background may not fully conform to the Chinese tourists to help explain their behaviours. Although tourism operators and managers can follow the traditional western standards in terms of tourist management, it is necessary to understand the characteristics, background and culture of Chinese young tourists, and to adapt to the specific tourism market, thus better serving the specific tourism market. Because motivation can be greatly influenced by individual characteristics, it is worthwhile to conduct specific research in the Chinese context to obtain more accurate research 
results, rather than relying solely on mainstream research results based on western tourists.

Therefore, as China's post-90s generation plays an important role in the global tourism market, it is necessary to study further and fill the research gap in Chinese youth tourism research and offer the youth tourism market more specific information about this special group.

\subsection{Thesis structure}

This thesis is divided into six chapters. The first chapter is a brief introduction to the whole thesis, including the origin of the post-90s and social changes in China, the main purpose of the study which is to find out the influential factors of tourism motivation of the post-90s generation, and the present issues of research on youth tourism and tourism motivation. Chapter two reviews the literature relevant to youth tourism and tourism motivation and points out the gaps that this thesis tries to fill. Chapter three is about the methodology of this research, providing the research context in detail, introducing the methods used to conduct the research, choose the sample and collect the data. Chapter four presents various results by analysing collected data, including the descriptive analysis of respondents, analysis of tourism motivation of respondents, factor analysis, and the analysis of the relationship between motivation and different social variables. Chapter five discusses the meaning of research findings and expounds their influences. Chapter six summarizes the whole research, stating several contributions of this study and also pointing out its limitations and the future research direction. 


\section{Chapter 2 Literature review}

\subsection{Youth tourism}

\subsubsection{Definition of youth tourism}

The concept of youth tourism has many broad definitions in specific literature; but so far, there is a lack of an agreed definition of youth in the world.

According to the United Nations, the term "youth" should be understood as a transitional period from childhood dependence on the outside world to adult independence and a sense of interdependence as a member of the community during this period (World Economic Forum, 2013). The World Tourism Organization defines that the youth are between the ages of 15 and 25. There are many studies targeting individuals with a maximum age of 26 years to provide better consistency for the research team (Horak \& Weber, 2000). Later, the Canadian Council and the Tourism Association of North American students extended this definition to include people up to 30 years old (Moisă, 2010). In defining the age limit for youth, Horak and Weber (2000) also emphasize the youth in the definition of youth tourism. Compared with a fixed age group, youth is a more fluid category.

The definition of "independent travel" refers to young people travelling alone without their parents or guardians (Richards, 2007). The concept of youth tourism mainly originated from and developed in western countries. At present, there is no specific definition of youth tourism in the field of tourism research in China. Chinese tourism research does not include the youth as a representative group for research and discussion. The concept of youth tourism is rather vague in the field of tourism research in China. The most famous definition applied was proposed by the United Nations Tourism Organization (UNWTO) in 1991: independent travel by young people who are between the ages of 16 and 29, lasting less than a year (UNWTO, 1991). This definition considers independent travel activities as important features that differentiate youth tourism from the travel of young people with their parents or guardians. Also, it covers an age range of 16 to 29 years, representing a broad age range of youth. In China, the post-90s people were born from 1990 to 1999. By 2018, they are aged between 19 and 28, belonging to the category of youth. Therefore, they are applicable to the research on youth tourism. 


\subsubsection{Characteristics of youth tourism}

Youth tourism is different from general tourism. The youth have their unique interests in and expectations for travel, which lead to significant characteristics of youth tourism. For example, usually, ordinary students cannot afford to stay in a five-star hotel and business-class air travel, and they will not choose advanced accommodation. As such, many of the descriptions of youth tourism suggest that an important feature of youth tourism is planning with a limited budget. Young people evaluate accommodation, destinations and values differently (Tleuberdinova \& Kikbayeva, 2016). Haigh (1995) describes youth tourists as young travellers who like to budget finance, time, and focus on meeting with other travellers independently or in an organized manner, and who have flexible travel plans that take longer time.

The specific tourism decision of the youth (Horak \& Weber, 2000) is related to the time budget, financial budget and the different groups of youth. Hence, we can perceive the characteristics that the youth are more concerned about how to stay more economically and practically at their destination over a long period of time.

In terms of financial budget, as young people prefer to spend more money on recreation, their purpose is to understand the culture, enjoy nature, experience adventure activities and so on. Generally, young travellers' economic ability is limit, and their travel is in a strict financial budget. Therefore, when choosing accommodation, they will consider the cost firstly, and give priority to affordable housing rather than a luxurious hotel. And not all young people are the same type of travel consumers. Firstly, those young tourists living in commercially operated hotels usually have no big differences from other tourists in terms of consumption patterns and behaviour. Second, those living in youth hostels, which are mainly prepared for young people and have a low price of accommodation, spend less on accommodation than on other things (Horak \& Weber, 2000).

Also, in terms of time budget, some young tourists want to create opportunities to socialize with other tourists through travel; this type of young travellers will spend more on the entire journey, because their travels usually take 4 times longer than those of other age groups (Horak \& Weber, 2000). 
Moreover, young people preferring youth hostels would like to make friends with those living in youth hostels. The youth hostels are not only for them to stay and sleep, but also to gain new experience (Horak \& Weber, 2000).

Last, Horak and Weber (2000) suggest that independent youth travel can be done individually, by several friends, or in groups (e.g., a full class, school, teacher group, scout group, etc.). Many young people prefer to take vacations with their peers and choose a destination that is more convenient for them to meet.

In addition, the role of education and the establishment of cognition and values are a prominent feature of youth tourism (Tleuberdinova \& Kikbayeva, 2016).

Tleuberdinova and Kikbayeva (2016) believe youth tourism is not simply for pleasure, but for understanding the world, expanding horizons, and spreading and building social culture. They emphasize that youth tourism is different from other types of tourism. In many cases, youth tourism will affect the career development of students. Through youth tourism, young people can develop various abilities, as well as strengthen and consolidate national values. At the same time, youth tourism is also a way of life. The youth are in a relatively free life stage, many of whom have not established a stable family and marriage relationship. Hence, they have fewer concerns. In this stage, to travel and see different scenery will give them more inspirations and choices to the right path in life, and help set goals for their life (Tleuberdinova \& Kikbayev, 2016).

The western study on youth tourism is mainly directed at young people who travel through the Boy Scouts, Youth Travel Association, Youth Holiday Association and other youth tourism organizations. Most of these organizations are non-profit and cooperate with national, regional or local tourism agencies to attract the tourism market. Their main aim is to provide young people with some of the tourism services they need. However, it does not mean that young people use these services only because of budget constraints. These services can not only meet their tourism goals and aspirations, but also separate them from the general tourist community. At the same time, the educational significance of travel is an elaboration of the characteristics of youth tourism, which distinguishes the youth from other tourists. Overall, these characteristics of youth tourism are significantly different from general tourism, revealing the youth's special needs for travel. 


\subsubsection{Types of youth tourism}

\subsubsection{Education tourism}

"Education tourism" refers to the type of tourism that participants travel as a group to another destination in the form of project activities, mainly for the purpose of creating learning opportunities and experiences related to the destination (Moisa, 2010). It includes heritage tourism, eco-tourism, rural/agricultural tourism, and student exchanges among different education institutions. Education tourism as a new concept emerging recently gets more and more popular in the tourism market. By providing overseas scholarship and tourism-related projects like hiking, the camp covers all stages of language courses and offers diversified training, such as medicine, law, tourism, management, design, fashion, theatre, art, dance, and so on. It changes the process of education and pattern, and enriches the educational experience. There are also summer schools and summer camps organized in various regions (Moisa, 2010).

The first official education tour was conducted by British youth during the Grand Tours of the 17 th and 18 th centuries. In the 18th century, the young aristocrats travelled from six months to three years. They believed that travel could help broaden their visions, and their travel mainly aimed to learn about the classical art of the time and cultural landmarks everywhere (Ritchie, et al., 2003).

In the past, people accepted knowledge more passively. However, now in China, various education tourism products emerge, including some unique types such as life education tourism, which has high-tech content and high-cultural quality. In the form of leisure and entertainment, the Chinese tourists learn new knowledge, enrich their life experience, and satisfy their consumption demand by education tourism.

\subsubsection{Volunteer tourism}

This type of travel refers to the practice that during the holidays, through an organizational approach, the individuals do voluntarily for some worthwhile causes. Many of them are public service volunteers. In volunteer work, they engage in specific activities, such as alleviating the material poverty in some regions, restoring some of the damaged environment, conducting research on some aspect of society or the environment, or participating in some general tours (Wearing, 2007). 
Volunteer tourism originated from the early 20th century when Swiss businessman Pierre Serreze founded the Service Citizen International (SCI) as the original volunteer organization form to help those in need (Tomazos \& Butler, 2009). In today's society, numerous volunteers learn volunteer services through various voluntary organizations, which facilitate the provision of volunteer services. The purpose of volunteer tourism varies with the background and expectations of participants. In addition, these organizations have organized more than 3,000 projects across 150 countries (Tomazos, 2010).

Volunteer tourism can be done domestically or internationally. The differences in the schedule and content may come from the project and volunteer organization. Some have a week for a vacation in total, but conduct an afternoon volunteering task at a local animal sanctuary; while others may take five days to build a house with just one day off. The length of time spent on volunteering and participating in tourism activities varies with the wishes of volunteers and the needs of receiving organizations (Demeter \& Bratucu, 2014).

\subsubsection{Work and travel programmes}

This type of youth tourism is very popular among young people who are enthusiastic about travelling. Throughout the project, they usually choose to work at a company in the summer (three months) or a longer vacation at a destination. They gain income through work, and the money also gives them the opportunity to travel. In this process, they can learn not only local customs but also the local language. They usually have a month to travel. The project originated in the United States and was initially organized by nongovernmental organizations. Since then, this form of tourism has become popular in Australia, Canada, Greece, Spain, France and the United Kingdom (Demeter \& Bratucu, 2014).

Till 2014 , more than $7 \%$ of the global youth tourism market is combined with overseas work in some form. The average consumption of these young travellers reached $\$ 3200,40 \%$ of which came from work at the destination (Demeter \& Bratucu, 2014). Young people who plan to travel in this way often get their information from their friends who have participated in organizational projects, and this form of travel usually lasts an average of more than six months (Demeter \& Bratucu, 2014). 


\subsubsection{Cultural exchange}

This form of youth tourism is seen as an individual exchange between different countries. This kind of communication, in the form of tourism, is generally aimed at students, artists and athletes. Generally, organizational communication should be conducted between different countries. If there are differences in various aspects, it can promote understanding and improve similarity. It also provides opportunities for people from different regions, with different social backgrounds and cultures, to improve their understanding of diversity. Through such activities, more opportunities can be created for people to learn and understand each other, and to gain new feelings and experiences outside of their communities. Cultural exchanges can help young people establish positive relationships with others, broaden their horizons, and develop and gain the skills and experience they need to live in a multicultural society (Demeter \& Bratucu, 2014).

The development of cultural exchanges among young people began after the end of the Second World War. Young people from different countries and regions increased exchanges to reduce the opportunities of cultural conflicts. For the cultural exchange of schools, usually, students of two or more different schools come together to interact and communicate face to face. Through this kind of activities, the youth have opportunities to live with host families, which can be long or short, from a week to a year. During this time, travellers are living with locals. If having a problem, they can help each other find solutions. For cultural exchange, the fundamental goal is to create opportunities for students to share experiences and learn from each other.

\subsubsection{Sports and adventure tourism}

Sports activities are increasingly becoming part of people's daily leisure and entertainment activities. The constant development of leisure culture also promotes the development of the sports tourism industry in the world. Sports tourism is a form of travel in which people leave their usual place of life to other places for observation or participation in one or more sports activities in person.

At the same time, adventure tourism is inseparable with the sports tourism industry, which can also be seen as a type of tourism. The travel activities often require 
exploration or actual risk during travel, or some professional skills and physical activities to complete (Demeter \& Bratucu, 2014). An important feature of adventure tourism is the risk and uncertainty of the travellers as a result of an intentional pursuit. In addition, the traveller himself or herself believes there is a danger or a certain challenge that can trigger a physiological/psychological surge of adrenaline. In essence, adventure tourism is mainly dedicated to creating adventure experiences and providing certain risks in the process. The survey shows that a higher proportion of travellers taking part in such trips are single adventure travellers, most of whom are men or have never got married (Ewert, 1989).

\subsubsection{Leisure tourism}

Leisure tourism involves the young, independent and adventurous travellers between the ages of 15 and 29 who visit friends and relatives or go on vacation. Since this group of travellers is mostly young, many of them have low-level income and are often sensitive to the budget and price of travel. However, they usually choose to increase their budget to pursue relaxing and comfortable experiences (International Youth Leisure market, 2014).

\subsubsection{Youth tourism development}

Youth tourism is not a new phenomenon. After emergence, its rapid development has attracted the attention of numerous travel-related researchers, tourism marketers, tourism decision-makers and other tourism-related industries. According to the United Nations World Tourism Organization, young tourists accounted for 20 percent of the 9.4 million international tourists in 2010 (UNWTO, 2011).

The development of the world tourism industry can well illustrate that the trend of tourism mobility depends on age, gender and marital status. The most active tourists are people aged from 18 to 30 , and single people are more mobile than those with families (Tleuberdinova \& Kikbayeva, 2016). Due to economic and other preconditions, a large proportion of young people do not leave the boundaries of their regional space. However, during this period, they often develop their perspectives on the historical characteristics of various regions in the world and their cognitive needs for different cultures (Tleuberdinova \& Kikbayeva, 2016). 
Horak and Weber (2000) study several factors that promote the development of youth tourism in Europe. The first is the increasing young people in major European countries. The data shows that the proportion of young people (15 - 24 years old) in these countries continued to decline in 2000 and then rose again in 2005, resulting in the same number of young people as in 1995. From the perspective of the development of youth tourism, the proportion of young people cannot be the limiting factor (ATI, 1995). Although China's insistence on the one-child policy in the 1980s led to a decline in the proportion of young people born in the 1990s, it was not a development constraint for youth tourism. China has the largest population; therefore, the total population in each age group is very large, and there is an absolute potential for market development. In the development of China's youth tourism, residents' consumption concept is changed as a result of economic growth. Since the reform and opening-up, China's society has become more and more stable. Also, the improved medical and health conditions increase the average life expectancy, and significantly reduce the death rate. As a result, the population scale steadily grows in China. At the same time, the urbanization rate rises rapidly. All of these phenomena have direct and indirect impacts on the end demand and the structure of the tourism market.

The second factor is the change in the social structure. Due to the continuous development of the economy, more and more young people are positioning themselves as middle class, and hence consciously pursue higher living standard and quality. Tourism is an activity that can reflect the improvement of living standards.

The third factor is related to the second factor. As time goes by, economic development brings about changes in the social structure. More and more young people enter universities. Students have a fixed holiday time and hence get more time to travel, especially on long distances. At the same time, higher education has also improved the cultural level of young people. With the increase in education and knowledge, young people have greater travel aspirations, and also higher enthusiasm and demand for overseas travel. According to UNESCO (1995), the number of students worldwide doubled between 1970 and 1991, and the base was estimated to be 79 million in 2000. This number increased to 97 million in 2015. Undoubtedly, the large increase in the number of students will certainly have a major impact on the number of young people in the foreseeable tourism market (Horak \& Weber, 2000). 
The latest youth travel report by the United Nations World Tourism Organization forecasts that there will be about 370 million young student travellers by 2020 .

According to the "China Higher Education Quality Report", China's social structure has changed with economic development; so has the proportion of the population. In 2015, the number of Chinese college students reached 37 million, ranking the first in the world (Ding, Xin, Jian, \& Yanhui, 2010). Among Chinese university students at present, the vast majority is post-90s. The number of Chinese college students also reflects the number of people receiving a higher education among Chinese post-90s to some extent. Most people in China's younger generation have higher education levels, and see themselves as middle class. Therefore, the travel demand of this group will foreseeably grow.

Another factor that can affect the future growth of youth tourism is the income of parents of young travellers. A study by the French National Union on French youth tourism shows that more than one-third of youth tourism is partially or wholly funded by their parents (Horak \& Weber, 2000). For China, parents' income is also significant in terms of economic support for young people to travel. According to China's sixth census in 2010, China has the largest population of those two age groups: $30-45$ years old and 15-25 years old. Also, people of 46 years old reach the peak point of population consumption expenditure. Therefore, taking factors such as career development, family environment and social security of Chinese employees into account, the age group of "35-45 years old" is the most consumptive population in China. The Chinese people aged 15-25 are a group that grows with the rapid development of the Internet. They have personalized consumption concepts and curiosity. During the period of 2010-2017, they gradually entered into the society and began to have certain consumption. Although their purchasing power is limited, they have different consumer attitudes and demands from other consumer groups and gradually become a beacon of major consumption trends. The two factors of the purchasing power and the trend group drive the change of current consumption. And from the data, most of the parents of the post-90s are in their 40s and 50s. They have high spending power and are mainly in the middle class. Their high spending power directly affects their children. Although the personal consumption ability of the post90s generation is limited, based on the consumption of their parents, their spending 
power is also to be reckoned with. In China's youth tourism market, the consumption of the post-90s generation is indeed growing.

Overall, the definition of youth tourism is still vague in academic filed, and the concept of youth tourism has not been discussed and studied on a large scale in China. However, it can be seen clearly that young age is the key point to define youth tourism. At present, the changing trend of Chinese tourism led by Chinese young people due to those factors gradually plays a big role in Chinese tourism development; therefore, tourism activities of the post-90s generation have gradually become essential and made a big influence on China's tourism. Youth tourism has so many similarities with general tourism, but there is still some uniqueness; therefore, it requires the tourism sector to pay more attention to the consumption power of China's younger generation and to do more detailed research.

\subsection{Tourism motivation}

\subsubsection{Definition}

Motivation, which is considered as the cause of human behaviour (Mook, 1996), is usually a need or a state of affairs that prompts a person to do some type of action to meet that need. Motivation is seen as the underlying force that causes and guides travel behaviour (Iso-Ahola, 1982). Generally speaking, tourists' motivation refers to a variety of social psychological factors, such as relaxation, escape, prestige and social contact, or cultural factors such as learning and novelty (Crompton, 1979). Because travel motivation plays a crucial role in determining travel behaviour, there are many studies on travel motivation in the academic field related to tourism.

Travel motivation is defined as a meaningful state of mind, which can fully deal with the travel activities carried out by actors or groups of actors. The joint travel motivation is defined as being able to effectively interpret travel decisions (Dann, 1981). The decision of the traveller to finally visit a particular destination is influenced by tourists' motives, values and backgrounds (Lue, Crompton \& Fesenmaier, 1993). Pierce (2011) argues that tourism motivation can be seen as a special subset of the broader interest field in human motivation, which is an overall network of biological and cultural forces providing various directions, behaviours, 
values and experiences for travellers' travel choices. Also, tourism motivation is generally regarded as the decisive factor of tourism activities, the reason for choosing a specific destination and being satisfied with travel (Castaňo, Moreno, García, \& Crego, 2003). Overall, tourism motivation can be explained as the deciding factor of the traveller's decision to travel, and it consists of a variety of factors.

\subsubsection{Theoretical approaches to tourism motivation}

There are several theoretical approaches to tourism developed by many researchers through socio-psychological and sociological ways. Iso-Ahola (1982) explains it in socio-psychological approaches and develops the tourism motivation theory, pointing out that all leisure activities originate from escape and search, and both motives are influenced by personal and interpersonal factors (Iso-Ahola, 1982). Iso-Ahola (1982) proposes a social psychology model, using two basic motivations to explain people's leisure behaviours. Here, leisure behaviours implemented in the context of tourism are included, namely escape and search. In this model, motivation is thought as a process, driven by expected psychological results. In particular, both of these basic motivational forces have different dimensions including personal and interpersonal (Iso-Ahola, 1982). People engaged in leisure activities like travel because of escape and search. On the one hand, they want to escape from some personal and/or interpersonal environment. On the other hand, people engage in leisure activities to seek and crave rewards for some personal and/or interpersonal relationships. Another theory developed by the socio-psychological approach is the travel career theory. On the basis of Maslow's (1970) hierarchy of needs theory, Pearce (1988, 1991, 1993), Pierce and Caltabiano (1983), Moscardo and Pearce (1986) developed the travel career ladder theory known as TCL. They divided the tourism motivation into five different levels of needs: relaxation needs, safety/security needs, relationship needs, self-esteem and development needs, and self-realization/satisfaction needs. In Maslow's theory, the needs of travellers are seen as a hierarchy or ladder. The needs for relaxation are at the bottom of the ladder, followed by safety/security needs, interpersonal needs, self-esteem and development needs, and finally, at the top, fulfilment needs.

Although many empirical studies on tourism motivation are based on the theory of social psychology, their theories don't explain why people choose "travel" to meet 
their needs rather than by other means or activities, such as family or religion (Ryan \& Geldon, 1998; Jamal \& Lee, 2003). In order to explain these problems, many sociologists include tourism motivation in their research scope (Rojek, 1995; Wang, 2000). They address that people get psychological benefits from the escape from everyday life or the stress environment, and they are looking for the chance of some intrinsic reward. Snepger et al. (2006) studied and tested the social psychological model. Using travel experience as the research background, they supported the theory proposed by Iso-Ahola (1982), i.e., tourism motivation consists of personal escape, interpersonal avoidance, personal and interpersonal pursuits.

Some researchers study the key role of human needs in tourism motivation. Kay (2003) points out that when researchers study motivation, there are four main methods they usually follow: demand-based, value-based, the benefit sought or realized, and the expectation theory. Among them, the demand-based method refers to the fact that a variety of different demands stimulate people's behaviour. The most famous theory of this method is Maslow's (1970) hierarchy of needs theory, Murray's (1938) classification of demand theory, and McClelland's (1955) academic demand theory. In terms of the values-based approach, the researchers explain the motivation by investigating and measuring the value of individuals. Through this approach, the researchers can predict the impact of personal values on people's motivation or behaviour and then segment the market. The approach of seeking or achieving benefits is to indicate the link between the incentives and the benefits derived from the purchase decision that may be based on attributes (e.g., tangible attributes of the destination), psychological aspects (e.g., emotional benefits of service expectations), or a combination of the two. The expectation theory is based on work motivation, which has been modified and included in the study of tourism motivation. The expectation theory means that people are motivated to carry out activities to obtain the desired results through the activities and the personal value that contains all the results related to the activities (Hsu, Cai, \& Li, 2010). From this perspective, it can be better explained that expectation and value motivation will have a certain impact on tourists' travel decisions and satisfaction. In the psychological approach, the basic intrinsic human needs and the alternatives offered by tourism are designed to meet the needs that arise when people experience a systematic imbalance of needs. 
In contrast, the sociological approach emphasizes that social structure has an impact on individuals' tourism behaviour (Jamal \& Lee, 2003). Sociologists generally use the modern contextualist approach to study tourism, summarizing tourism motivation based on social changes in the world. This method believes that the formation of tourism activities is not important only because of individual biological or psychological status, but more about social and cultural issues (Wang, 2000). It emphasizes that any change in the global environment and structure can have a degree of impact on one's needs and expectations and their subsequent motivations (Burns \& Holden, 1995; Wang, 2000). At the same time, the individuals' motivation is actually more directly affected by their family circumstances. Because the continuous development and changes of society greatly change lifestyle, people constantly experience more divisions in daily life; while their interpersonal relationship and the surrounding interpersonal environment will also follow such changes, decentralization and authenticity (MacCannell, 1976). These changes have led to the confusion and distortion of people's habitual life, prompting them to escape their family circle, seek the authenticity and self-improvement by travelling, thus enjoying and obtaining the products, services and facilities provided by the destination (Dann, 1981).

Although many researchers have used some well-known sociological theories to explain travel behaviours, such as staying away from social disintegration (Dann, 1977), or seeking meaning for survival in modern life, psychological needs are generally considered as the motive factors of travel. Therefore, tourism motivation is a theory of common conceptualization, based on tourists' internal and external motivations, which are summarized as "push" and "pull" respectively (Crompton, 1979). The push-pull framework is a commonly used method to explain tourists' travel behaviour and travel motivation (Fluker \& Turner, 2000). Among them, the "push motivation" is described as the one that determines the travellers to have a trip, and comes from the inner strength of the travellers (arguably because of the psychological need to travel outside of daily life). The "pull motivation" is described as a force from outside, such as the attributes of a destination. It can explain why travellers choose one destination over another once they decide to travel (Albayrak \& Caber, 2018). More specifically, the motivation of tourism is interpreted as "push" and "pull" frame. The "push" factor is the psychosocial motivation that drives individuals to decide on travel activities (Crompton, 1979; Prayer \& Hosha, 2008), 
such as escape, relationship, relaxation, knowledge, self-esteem, family reunion and leisure and recreation, all of which are the driving factors (Buckley, McDonald's, Duan, Sun \& Chen, 2014; Crompton, 1979; Fluker \& Turner, 2000; Klenosky, 2002). The "pull" factor is related to the characteristics and attributes of the destination. There are various factors including the weather of travel and destination, destination scenery, tourist attractions, physical facilities, air ticket price, history and culture of the destination, etc. (Dann, 1997; Fluker \& Turner, 2000)

Furthermore, when studying the push-pull model, researchers usually pay attention to the differences between push-pull factors (Dann, 1977; Crompton, 1979). As described above, "push" is usually defined as the factor that influences people's decision to travel; while "pull" is usually defined as the factor that influences people's decision on a certain type of vacation. Dann (1977) proposes that anomie and selfimprovement can be regarded as the two major underlying motives for travel, and they are both driving factors. Through the interview, Crompton (1979) discovered and summed up nine different tourist motives, then further divided them into psychological needs, cultural needs, and social needs.

In addition, based on the results of Dan's (1977) empirical research, Crompton (1979), Pierce and Caltabiano (1983), and Fodness (1994) proposed the method of using different functions to interpret tourism motivation. According to the results of factor analysis, five different functions are summarized, including two practical functions, namely, minimizing punishment and maximizing reward; two functions of value expression, which are self-improvement and self-esteem; and the function of "finding knowledge". The above five functions are considered as the foundation of tourism motivation.

Measurement and investigation of tourism motivation become the key to predict tourists' future demand and develop products, thus meeting tourists' demand and attracting more tourists (Wolfe \& Hsu, 2004). However, according to Bright (2008), tourism motivation is always complicated to be studied if it is placed in the background of psychological theory. Therefore, the theory of tourism motivation should not be static and single, but dynamic and flexible in different situations of tourists (Pearce, 1993). 
Overall, motivation theories can be interpreted from different perspectives and they are diversified; however, it can be basically agreed that only one human motivation cannot support tourism research (Iso-Ahola, 1980; Kay \& Meyer, 2013; Pearce \& Lee, 2005). Therefore, since the research focuses are different, the theoretical methods of studying tourism motivation also vary.

The Chinese post-90s generation is the target subject of this study. The tourism of this group has become a unique trend in contemporary China, and its reasons are closely related to the social background of China. Since the 1980s and 1990s, there have been changes in China's social environment and policies, and the rapid development of the media, the Internet, science and technology. Consequently, the unique and avantgarde ideological culture is the reason why this generation gradually becomes the focus of Chinese society. Also, because of the effect of different cultural and social backgrounds, Chinese tourists' thinking mode and behaviour mode are greatly different from those of western tourists. Jensen (2012) studied the characteristics of Danish tourists and found that their income level had nothing to do with their social connections, reputation and impression. The study by Bieger and Laesser (2002) also showed that Swiss travellers, ranking the first in the world in terms of income, were driven more by natural or cultural factors than by social or family factors. However, the results of the study conducted by Anson (2018) show that the monthly income of Chinese tourists is positively correlated with social motivation. In other words, social factors have a great impact on the tourism motivation of Chinese tourists. Therefore, in the study focusing on the Chinese tourism market, especially targeting the specific age groups in China, it is necessary to consider the social context and demographic characteristics. As the target of this research is the Chinese youth, who are significantly impacted by China's social changes, it is believed that sociological factors do have a great influence on the tourism motivation of the post-90s generation in China. Therefore, the sociological approach is considered to be the most suitable to study their tourism motivation. 


\subsubsection{Empirical studies of tourism motivation}

\subsubsection{Review of empirical findings of tourism motivation}

Pearce and Lee (2005) conducted a study in the form of interview and questionnaire survey. They proved that travel motivation could be a pattern and combination of multiple motivations, and the previous travel experience and age of travellers had an impact on these motivations. Pearce and Caltabiano (1983), Woodside and Jacobs (1985) point out that previous travel experiences can make a big difference in learning about travel motivations and providing advice. At the same time, the study results of Pearce and Lee (2005) showed that novelty, relationship and self-development, avoidance/relaxation were the core motivations of all travellers. Especially, people with a high level of travel experience paid more attention to the motivation of selfdevelopment through websites and natural seeking. People with low travel experience paid more attention to other motivational factors such as stimulation, personal development, self-fulfilment, safety, nostalgia, romance and recognition. Although the study was not designed to directly measure past experiences, the majority of respondents (62\%) said that they travelled more than twice a year. Visiting new places and experiencing new things, visiting museums, visiting historic sites, escaping and relaxing, and spending time with family were reported to be the most important reasons to travel. Although there are various researches exploring different tourist motives, the results of the study conducted by Pearce and Lee (2005) showed that without considering their travel experience, under the influence of travel motivation mode, basic and novelty, escape/relaxation, relationships, and self-development were the four central factors of tourism motivations. The motivation of self-development can be divided into two categories, personal development and host-site development. The motivation for personal development is more likely to come from people with less travel experience; if they are more experienced in travel, their motivation for participation becomes more apparent. As a result, beyond the core motivational factors, travellers' tourism motivations remain uncertain and require specific research. Moreover, compared with the changing travel experience, these core motivations will not change much.

Through the sociological theoretical approach, Li, Zhang, Xiao, and Chen (2015) studied the tourism motivation of Chinese tourists considering social and cultural 
influences. According to the research results, five factors that may impact tourism motivations were summarized, including novelty, knowledge, relaxation, entertainment, self-development and escape, in the order of importance, from most to least. The average scores of all these dimensions were above 4 , showing their significant influence on tourism motivation of Chinese tourists.

\subsubsection{Review of empirical findings of youth tourists' motivation}

The research on youth tourism motivation is also carried out on the basis of the study on general tourism motivation, which is consistent with the results of some studies on tourism motivation. However, due to the differences in age range, some contents different from general tourism motivation also appear in the research results on youth tourism motivation. There are some empirical studies conducted to research the tourism motivation of the youth. Richards and Wilson (2003) concluded from their study that among the young people's motives for tourism, several factors of motives are most related to tourism motivation of the youth. The first is culture. The purpose of cultural tourism is to visit places of interests. Most of the young travellers are more interested in learning about cultures in different regions. They like to meet new friends and explore places they haven't been to (Richards \& Wilson, 2003). The second is the volunteer service. Young people get a sense of accomplishment by helping people who live in bad condition (Sin, 2009). The third is education. Young people learn different languages and are usually interested in certain topics, such as leadership, acting, speech, globalization, history (Demeter \& Btucu, 2014). The fourth is work and travel. Young people work with the residents of travel destinations and workers from all over the world, sharing and exchanging cultures and traditions of their countries and regions during this period (Moisă, 2010). The fifth is sports and adventure; it is an important way to meet the specific needs of young people. According to their free time and the way to spend it positively, they often choose to do sports in different natural environments, such as bungee jumping, skiing, surfing, climbing, climbing, etc.

In addition to the travel motivation of traditional tourism (Bywater, 1993), especially, culture and education are always taken into account in the study of tourism motivation. Bywater (1993) points out that there are two special types of motivations to be identified in youth tourism: one is the desire to understand the culture of the tourist 
destination, and the other is the education in different forms. The youth travel document by New Delhi (1991) points out that "to learn to travel" is very important because it focuses on both motivations. Some organizations also cater for such motive and establish some projects. For example, some related international association and tourism management organization have set up youth exchanges between projects. There are foreign language courses provided for young people, which become one of the important services of many travel agencies and tour operators. However, these types of tourism motivations are typological for tourism study. In the Chinese context, since the study targets people who were born from 1990 to 1999 , it is uncertain that those types can cover their whole tourism motivations. Therefore, an empirical study that focuses on this population is needed, so as to identify and generalize the tourism motivations of the Chinese post-90s generation. 


\section{Chapter 3 Methodology}

\subsection{Research context}

Contemporary China is under huge and profound institutional changes as well as the transformation from a planned economy to a market economy (Shuguang, 2017). This is an extremely complex process. It is not a partial change of some arrangements in the original system structure, but a comprehensive reform of the whole system structure. It is not only about marginal adjustments in the operation process of the current system rules, but also about the reconstruction of the whole economic order and economic life. Over a decade, China has formed a reform model and development path with Chinese characteristics, commonly known as the "China model", resulting in today's development situation in China (Shuguang, 2017).

Along with the rapid development of information technology, the industry of mass communication media is flourishing in China. TV, movies, the Internet and other media are playing an increasingly important role in life, especially for the post-90s generation. Also, the development of China's mass media, social media and the Internet provides a good information platform for the youth, enabling them to receive comprehensive and convenient information and promoting their all-round development.

Meanwhile, China's education is also making continuous progress. In particular, higher education is developing rapidly and its penetration rate is expanding continuously. Since 2000, the gross enrolment rate has maintained an average growth rate of 1.5 percent, reaching 23 percent in 2007 (Ding, Xin, Jian, \& Yanhui, 2010). The number of students enrolled in higher education institutions of all kinds and at all levels has exceeded 25 million, even surpassing that of the United States and ranking the first in the world (Ding, Xin, Jian, \& Yanhui, 2010).

In terms of policies, in the 19th century, China began to implement the family planning policy in order to improve living standards and population quality. Since 1971, the family planning campaign has been officially launched, starting with the propaganda theme: one child is not enough, two children are ok, and three children are too many. Through the campaign, China's overall fertility rate fell by half between 1971 and 1978 (Junsen, 2017). In the next decade, the family planning policy was 
relaxed. However, in 1986, the country reiterated and emphasized the importance of the one-child policy, and tightened the policy nationwide from 1986 to 1990 . Since 1990, the one-child policy has been relatively stable; hence most children born after 1990 are the only child in the family (Junsen, 2017).

Under this background, as the research subject, Chinese post-90s generation who can be seen as the youth was born in a special period, which helps create their unique personality and characteristics. The Chinese researcher Hongmei (2012) conducted an in-depth study on China's post-90s generation. She reported that this generation was born in the period when China's policy of reform and opening up made remarkable achievement, and China made efforts to improve its international status; at the same time, China's exchanges more closely with the rest of the world promoted the cultural diversity in society. Therefore, the post-90s develop their uniqueness of life attitude which can be seen from their performance. Under the favourable education environment and conditions, while recognizing the importance of ideal and belief, Chinese post-90s have clearer life goals and reasonable plans, showing the optimistic, confident, self-reliant spirit and life attitude (Hongmei, 2012).

Most people among China's post-90s generation are the only child in the family because of the one-child policy; they have been favoured by the whole family since childhood. Many young people try to show their personality, while the sense of collectivism is increasingly weakened by individualism (Hongmei, 2012). Since most of the parents of China's post-90s generation experienced the resumption of the college entrance examination, they have a higher level of education than older generations. Therefore, they have a relatively new education concept, respect and value their children's equal right to speak, making the post-90s generation more idealistic (Hongmei, 2012).

Moreover, the all-round development of education makes the post-90s students more open-minded, have strong learning ability, accept new things quickly, be full of innovation spirit, and have strong selectivity, personality and independent ideas. In addition, schools have a strong cultural atmosphere, and the teaching staffs are mainly well-qualified intellectuals. These factors play a very important role in the healthy growth of the youth. They have begun to accept the culture of other countries and ethnic groups (Hongmei, 2012). Therefore, the diversity of values also becomes their 
characteristics. They are a generation with an outstanding personality and competitive spirit, eager to be recognized by others. They have greater enthusiasm for respected teachers, expectations and attention to themselves, and are more receptive to education and guidance (Hongmei, 2012).

With the development of economy and the improvement of living standard in China, the Chinese post-90s are surrounded by modern information, and their consumption level is high. And they have certain psychology of seeking for differences in their consumption, which is closely related to the publicity of their personality. They hope to make themselves unique through consumption.

It can be seen clearly that the post-90s people as Chinese youth have their unique characteristics due to China's social changes. These characteristics are also reflected in their behaviour pattern. Meanwhile, since China's post-90s generation have become a more powerful consumption force in the tourism market, China's youth tourism market is gradually becoming more mature. These unique characteristics of China's post-90s generation have attracted wide attention.

\subsection{Research design}

In general, this study identifies the research questions, collects data through quantitative research, answers the questions, and verifies the hypothesis. It takes the Chinese post-90s as the survey object, selects part of the samples through convenience sampling, collects the data through an anonymous questionnaire survey, both online and offline, and then analyses the collected data, summarizes the conclusions to answer the research question. As the positivist paradigm begins with an assumption that a fact exists, on this basis, the quantitative research method verifies the reality and improves its effectiveness by a careful sampling of data, appropriate tools and statistical processing (Cohen et al., 2000). Positivism is the theoretical basis of this research approach, and quantitative research is the research approach of this study. The quantitative research approach is selected mainly because it can measure, quantify or discover the degree of a phenomenon and pays more attention to the description of a specific experience. In positivism, reality can be interpreted as the result of a cause (Patton, 2002), and quantitative research is considered as a kind of empirical research. The choice of quantitative research indicates that the focus of this 
study is verifiable observation. Quantitative research is to collect numerical data from a group of people, which is usually expressed in numerical terms, and then extend these results to a larger group of people with the same attributes as the subject to explain a phenomenon (Djamba \& Neuman, 2002). To explain what they see and its effects and to have objective and conclusive answers, scholars will choose quantitative research as the research method. As a whole, people use quantitative research to describe the results obtained in the research, and further summarize and analyse the results to obtain specific and descriptive conclusions (Neuman, 2011). This study explores the tourism motivation of Chinese youth based on the social background of China. It aims to find out the tourism motivations of the current Chinese youth. Because quantitative research can provide a relatively conclusive answer to research questions, especially when data are collected and analysed using the standard and effective methods, the results are usually reliable (Simpson \& Lord, 2015). The analytical results obtained in this way can be extended to the whole range of research objects targeted by the study. The goal of this study is to collect some relevant data of China's post-90s generation, analyse and summarize the factors that affect the tourism motivation of these Chinese youth, and then extend the phenomenon to the whole Chinese youth as the target group. And survey research is selected as the method of quantitative research in this study, to understand a large number of target populations by investigating a certain number of demographic samples (Neuman, 2011).

For sampling methods, convenient sampling and snowball sampling method are used to select participants. The network of the researcher is used to contact people who meet the pre-condition (more information about sampling is detailed in Section 3.4) and to invite them to participate in this survey. Therefore, convenience sampling can reach the people who meet the requirement more effectively. For snowball sampling, people help to contact more young people they know who meet the standards to participate. This method can reach a large number of participants within a limited time.

\subsection{Survey instrument}

This survey is mainly used to collect the motivations of overseas travel of 
Chinese post 90s generation. In order to obtain more accurate research results, it is necessary to draw conclusions from a large number of data. Considering the time and budget limit of this study, the questionnaire method is selected as the instrument to get participants' ideas. The main question of this study is to find out the important factors affecting the travel motivations of the Chinese post 90s generation. The sub-questions are listed below:

1. What are the motivations of the post-90s generation for travelling abroad?

2. Is there a significant relationship between the Chinese One-child policy and the motivations of the post-90s generation for travelling abroad?

3. Is there a significant relationship between the influence of Chinese media and the motivations of the post-90s generation for travelling abroad?

4. Is there a relationship between the education level and the motivations of the post-90s generation for travelling abroad?

These questions are to achieve the research aim and help deeply understand the influential factors of Chinese youth's tourism motivation and the influence of China's social changes on youth tourism. Therefore, the questionnaire is designed based on the core question, which is determined by reviewing relevant literature and findings of previous qualitative research. It has total 17questions in three sections including the travel experience of participants, travel motivations and factors that influence motivations, and demographic information of participants. At the beginning of the survey, participants were asked 3 questions related to their travel experiences to know their travel decision and consumption behaviour. Then the total 27 measurement items including 24 statements in section 2 were used to learn the participants' tourism motivation and the influential factors. Motivational items listed in the questionnaires refer to the previous research by Zhang, Xiao, and Chen (2015) and Pearce and Lee (2005) who generated the motivational items and used them to identify tourism motivation. Therefore, this study also uses these items to study the travel motivation of Chinese youth. In order to indicate the degree of agreement of each statement, a Likert scale is used in the questionnaire. And in order to reduce the frustration level of patient respondents and increase response rate and response quality, a 5-point Likert scale is chosen (Jang \& Wu, 2006; Li, Zhang, Xiao, \& Chen, 2015; Linh, 2015; Pearce, \& Lee, 2005). Participants were asked to answer the statements on a 5-point Likert scale ranging from strongly disagree (1) to strongly agree (5). These questions are developed based on a comprehensive review of travel motivation literature from 
Linh (2015), Li, Zhang, Xiao, and Chen (2015), Pearce and Lee (2005), and Moscardo (2011). The main questions are designed and modified based on the above source (see Appendix A).

This questionnaire is designed targeting the Chinese youth, considering the social changes and technology influence. Thus, the new items including the Chinese media and policy that are related to the Chinese social background are involved to find out the influential factors. Also, since the section on travel motivation may not cover all possibilities, open-ended questions are developed to investigate the factors that participants believed affected their travel motivation. Finally, there are 6 questions about demographic information such as age, gender, income, current place of residence and hometown.

\subsection{Samples, data collection, analysis}

Since this survey is targeted at the Chinese post 90 s generation, there is a restriction on the age of potential participants. Each participant should be born between 1990 and 1999. There are some specific characteristics of the people recruited:

1. having overseas travel experience in the past 3 years;

2. having the purpose of travel of leisure (including working holidays).

The sampling frame is based on geographic location. According to the "Top 20 Outbound Tourism Departure Cities in the First Half of 2017" (China international travel mart, 2017), the first-line and coastal developed cities are the main force, and the top 10 cities for outbound travel are: Shanghai, Beijing, Guangzhou, Chengdu, Shenzhen, Hangzhou, Nanjing, Wuhan, Tianjin, Chongqing, Xiamen, Changsha, Kunming, Xi'an, Shenyang, Harbin, Nanning, Fuzhou, Qingdao, Ningbo. At the same time, people's frequency of outbound travel in these cities is also high. In the first half of 2017, the proportion of tourists who had 2 or more outbound travel experiences in the top 10 source areas reached 25\% (China international travel mart, 2017). Therefore, participants are from major cities in China including Chengdu, Shanghai, Shenyang, Xi'an, Nanjing, Guangzhou and Beijing. 
Data were collected in the form of a self-administered questionnaire, which was prepared in English and translated in Chinese. The questionnaires were distributed both offline and online. Since in reality, the Chinese are more familiar with the paper questionnaire, hand-written responses can increase the validity of the answers and make the data more reliable. For people who received the questionnaires in paper form, they completed the questionnaire in places where it is quiet and convenient. In Chengdu, Shanghai, Shenyang, Xi'an, Nanjing, Guangzhou and Beijing, paper questionnaires were filled out at the local downtown cafe and the city library. Some people from the researcher's network helped to distribute the handout. To assure anonymous, closed box and envelope were prepared for data collection. The questionnaires completed were placed in an envelope of a sealed box, so that the researcher and the one who distributed the hard-copy questionnaire could not see the answered questionnaire and match with the person who returned the questionnaire. Also, questionnaires were distributed to the post 90s generation who met the preconditions abovementioned from various big cities in China including Chengdu, Shanghai, Shenyang, Xi'an, Nanjing, Guangzhou and Beijing. The online form was used to reach the responders living in overseas and remote areas via emails. For online questionnaires, a website link was created from Qualtrics for participants, and all data were considered to be confidential. Qualtrics ensure that data are protected from hackers. The survey was conducted in the 2-month period from January to March 2019. There are 264 questionnaires collected, all of which are valid.

After collected, the questionnaires are processed and analysed through the Statistical Package for Social Sciences (SPSS). And various statistical techniques are used to generate the results: descriptive analysis, factor analysis, correlation test, ANOVA and post-hoc, and T-tests. Descriptive analysis is used to analyse the demographic characteristics of respondents. Factor analysis is to identify tourism motivation of respondents. Correlation analysis is to identify the relationship between tourism motivations and different social variables. ANOVA test and post-hoc are used to verify the differences in tourism motivation between different variables. The T-test is used to verify the difference in tourism motivation between the two groups. 


\section{Chapter 4 Results}

\subsection{Descriptive analysis}

\subsubsection{Respondents characteristics}

Firstly, from the results, the respondents have an average of 1.8 times of independent trips without family members each year. Secondly, as Table 4.1 shows, among the respondents, males account for $54.9 \%$, which is slightly more than females of $45.1 \%$. The overall ratio of males to females is relatively average, but there is still a slight difference. It can also be seen from the result that there is a big gap in the income of the responders. Among them, those with an annual income of "more than or equal to 80,000 RMB ( $\approx$ USUS\$11910) and less than 130,000 RMB ( $\approx$ US\$19355)" are the most, accounting for $45.1 \%$. Meanwhile, $28.8 \%$ of the respondents have an annual income of "more than or equal to $30,000 \mathrm{RMB}(\approx$ US\$4466) and less than 80,000 RMB ( $\approx$ US\$11910)". In addition, the result shows that the education level of the respondents is generally high. Only $1.1 \%$ of the respondents have no high school diploma, while $46.2 \%$ have a bachelor's degree. In particular, more than half of the samples $(51.5 \%)$ have a master's degree. And $78 \%$ of the respondents are the only child in the family. 
Table 4.1 Summary of demographics characteristic

\begin{tabular}{|c|c|c|c|}
\hline Characteristics & Evaluation & Frequency & $\%$ \\
\hline \multirow[t]{2}{*}{ Gender } & Male & 119 & 45.1 \\
\hline & Female & 145 & 54.9 \\
\hline \multirow[t]{5}{*}{ Income } & Less than $30000 \mathrm{RMB}(\approx \mathrm{US} \$ 4466)$ & 41 & 15.5 \\
\hline & $\begin{array}{l}\text { More than or equal to } 30,000 \mathrm{RMB}(\approx \mathrm{US} \$ 4466) \\
\text { and less than } 80,000 \mathrm{RMB}(\approx \mathrm{US} \$ 11910)\end{array}$ & 76 & 28.8 \\
\hline & $\begin{array}{l}\text { More than or equal to } 80,000 \\
\operatorname{RMB}(\approx \text { USUS } \$ 11910) \text { and less than } 130,000 \\
\operatorname{RMB}(\approx \text { US } \$ 19355)\end{array}$ & 119 & 45.1 \\
\hline & $\begin{array}{l}\text { More than or equal to } 130,000 \\
\operatorname{RMB}(\approx \mathrm{US} \$ 19355) \text { and less than } 180,000 \\
\operatorname{RMB}(\approx \mathrm{US} \$ 26799)\end{array}$ & 14 & 5.3 \\
\hline & $\begin{array}{l}\text { More than or equal to } 180,000 \\
\operatorname{RMB}(\approx U S \$ 26799)\end{array}$ & 14 & 5.3 \\
\hline \multirow[t]{4}{*}{ Education level } & Below high school & 3 & 1.1 \\
\hline & Undergraduate degree & 122 & 46.2 \\
\hline & Master degree & 136 & 51.5 \\
\hline & $\mathrm{PhD}$ & 3 & 1.1 \\
\hline \multirow[t]{2}{*}{ only child } & Yes & 206 & 78.0 \\
\hline & No & 58 & 22.0 \\
\hline
\end{tabular}

$\mathrm{N}=264$

The respondents in this survey come from a variety of cities, and the vast majorities are from these cities (see Figure 1): Qingdao (1.5\%), Shenzhen (2.6\%), Xi'an (2.6\%), Wuhan (2.7\%), Changsha (2.7\%), Nanjing (2.7\%), Tianjin (2.8\%), Kunming (3\%), Guangzhou (3.4\%), Hangzhou (3.8\%), Chongqing (4.2\%), Shanghai (7\%), Beijing (7\%), and Chengdu (31.4\%). 


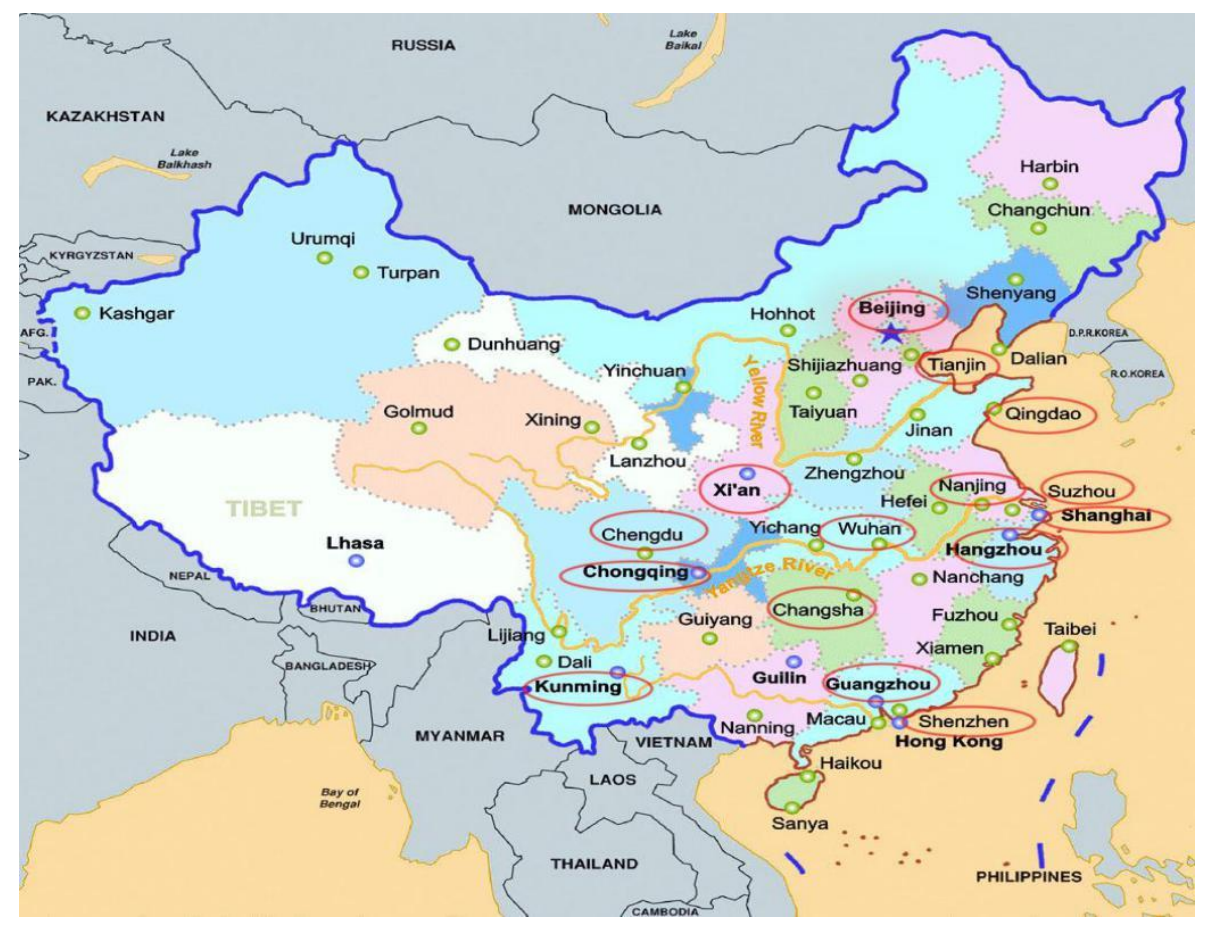

Figure 4.1 The main cities of China that participants come from

(Source: Form https://China tour map.com.cn)

\subsubsection{Tourism motivations}

According to the analysis result shown in Table 4.2, the average of the mean scores of the 25 items is relatively high. Among a total of 25 motivation measurement items, the mean value of the item "To have romantic relationships" (Mean $=3.41, \mathrm{SD}=$ 1.591 ) is the lowest. And 17 items have mean values higher than 4.00, indicating that on many items, the participants agree strongly. Among them, the item "To experience something different" (Mean $=4.53, \mathrm{SD}=0.729$ ) has the highest mean value, indicating that most of the participants in the survey strongly agree that their travel is driven by the motivation to experience something different. And, the mean value of the item "To experience the local conditions and social customs of the destination" (Mean $=4.48, \mathrm{SD}=0.823)$ also reaches 4.48 . This shows that most respondents strongly agree with the two items; in other words, the motivations mentioned in these two items are important for them. 
Table 4.2 Descriptive analysis result of tourism motivations

\begin{tabular}{|c|c|c|}
\hline & Mean & $\begin{array}{r}\text { Std. } \\
\text { Deviation }\end{array}$ \\
\hline To experience something different & 4.53 & .729 \\
\hline To experience the local conditions and social customs of the destination & 4.48 & .823 \\
\hline To enjoy the natural scenery of the destination & 4.51 & .785 \\
\hline To visit places related to my personal interests & 4.45 & .831 \\
\hline To see celebrities & 3.68 & 1.419 \\
\hline To Feel the special atmosphere of the destination & 4.28 & .985 \\
\hline To gain a sense of accomplishment & 3.74 & 1.350 \\
\hline To have romantic relationships & 3.41 & 1.591 \\
\hline To be free to act the way I feel & 4.09 & 1.118 \\
\hline To understand more about myself & 3.92 & 1.235 \\
\hline To have others know that I have been there & 3.53 & 1.472 \\
\hline To feel inner harmony/peace & 4.19 & 1.102 \\
\hline To meet new and varied people & 3.94 & 1.200 \\
\hline To be away from daily routine & 4.23 & 1.125 \\
\hline To be away from interpersonal relationship (family, friends, colleague...) & 3.75 & 1.417 \\
\hline To Shop & 3.96 & 1.189 \\
\hline To have fun or be entertained & 4.26 & .992 \\
\hline To visit the cultural and heritage sites & 4.06 & 1.144 \\
\hline To experience culture and conventions & 4.32 & .922 \\
\hline To visit the places I have read from books & 4.08 & 1.158 \\
\hline To visit the places I saw on TV and/or movies & 4.19 & 1.029 \\
\hline To visit the places I learned about on social media & 4.26 & .911 \\
\hline To know more about the political and social environment & 3.76 & 1.351 \\
\hline To find a place to have a rest & 4.10 & 1.116 \\
\hline To release my work/study pressure & 4.39 & .882 \\
\hline
\end{tabular}

Note: $\mathrm{N}=264$; items are measured in a 5-point Likert scale where 1 indicates 'Strongly disagree' and 5 indicates 'Strongly agree'. 


\subsubsection{Travel experience}

As can be seen from Table 4.3, there are varied average costs of travel. Nearly half of the respondents, accounting for $45.5 \%$ of the total, spend an average of between $10,000 \mathrm{RMB}(\approx \mathrm{US} \$ 1489)$ and $15,000 \mathrm{RMB}(\approx \mathrm{US} \$ 2232)$ each time they go abroad. And, $33.3 \%$ of respondents spend an average of between 5,000 RMB ( $\approx$ US\$744) and 10,000 RMB ( $\approx$ US $\$ 1489$ ). Only $3.5 \%$ of the respondents, the lowest proportion, have an average consumption of more than 20,000 RMB $(\approx U S \$ 2977)$.

In terms of the accommodation selected by the respondents, $63.6 \%$ of the respondents choose the economy hotel, and $20.8 \%$ choose the youth hostel; only $11.7 \%$ choose the luxury hotel. In particular, there are $2 \%$ of respondents who choose home-stay instead of the usual hotel.

Also, Table 3 shows that more than half of the respondents, accounting for 55.5\%, choose social media to get travel information; $31.8 \%$ use TV to obtain travel information; only $9.8 \%$ choose newspapers or magazines. The number of people who choose broadcast is the least, reaching only $3.5 \%$.

Table 4.3 Descriptive analysis result of travel experience

\begin{tabular}{llc}
\hline Travel experience & & $\%$ \\
\hline Average cost & Less than 5,000 RMB $(\approx \$ 744)$ & 8.0 \\
& More than or equal to 5,000 RMB $(\approx \$ 744)$ and less than & 33.3 \\
& $10,000 \mathrm{RMB}(\approx \$ 1489)$ & 45.5 \\
& More than or equal to 10,000 RMB $(\approx \$ 1489)$ and less than & \\
& $15,000 \mathrm{RMB}(\approx \$ 2232)$ & 8.0 \\
& More than or equal to $15,000 \mathrm{RMB}(\approx \$ 2232)$ and less than \\
& 20,000 RMB $(\approx \$ 2977)$ & 5.3 \\
& More than or equal to 20,000 RMB $(\approx \$ 2977)$ & 11.7 \\
& Luxury hotel & 63.6 \\
Accommodation & Budget hotel & 20.8 \\
& Youth hostel & $2 \%$ \\
Use of media & Newspaper/magazine & 9.6
\end{tabular}


$\mathrm{N}=264$

\subsection{Factor analysis of travel motivations}

The varimax rotation factor analysis is performed on the studied items. Kaiser-MeyerOlkin $(\mathrm{KMO}>0.6)$ and Bartlett's test of sphericity $(\mathrm{p}<.001)$ are used to measure the sampling adequacy and suitability of variables (Mimi, \&Hanqin, Hongchen \&Yao). The greater the value of the KMO is, the more common the factors are in the variable, and the more suitable it is for the analysis of factors. It is generally considered that if KMO is less than 0.5 , then it is not suitable for the analysis of factors. The results show that the KMO value is 0.955 , which is suitable for factor analysis. The detection method adopted in this survey is the Cronbach's consistency coefficient (Cronbach's Alpha coefficient). The reliability $\alpha$ is 0.970 , which is greater than 0.9 . Therefore, the data has high consistency and credibility. Considering that the eigenvalue is higher than 1 , the process produces three factors that explain $70.552 \%$ of all variables. Items with a factor load of less than 0.50 are deleted. According to the result of factor analysis, the load values of the two items including "To feel inner harmony/peace" (Mean $=4.19, \mathrm{SD}=1.102)$ and "To visit places related to my personal interests" (Mean $=4.45, \mathrm{SD}=0.831)$ are lower than 0.5 ; thus these two items are deleted, and the following three factors are extracted (see Table 4):

Factor 1: Self-development and relationship;

Factor 2: Novelty;

Factor 3: Escape and relaxation.

Meanwhile, it can be seen from Table 4.5 that the mean values of the three factors are 3.8437, 4.3668 and 4.1641 respectively. The mean values of factor 1 (Selfdevelopment and relationship) are the lowest; that of factor 2 (Novelty) is the highest. It indicates that novelty is the most important motivational factor. Therefore, the research question 1 is answered by the conclusion that novelty is the most important motivations of the post-90s generation for travelling abroad. 
Table 4.4 Descriptive analysis of three factors

\begin{tabular}{lrr}
\hline & Mean & Std. Deviation \\
\hline F1: Self-development and relationship & 3.844 & 1.082 \\
F2: Novelty & 4.367 & .742 \\
F3: Escape and relaxation & 4.164 & .884 \\
\hline
\end{tabular}

Table 4.5 Factor analysis result

\begin{tabular}{|c|c|c|c|c|c|}
\hline & \multicolumn{5}{|c|}{ Factor loading } \\
\hline & Mean(SD) & F1 & $\mathrm{F} 2$ & F3 & Comm \\
\hline Self-development and relationship & & & & & 0.795 \\
\hline To have others know that I have been there & $3.53(1.47)$ & 0.776 & & & 0.784 \\
\hline To have romantic relationships & $3.41(1.59)$ & 0.77 & & & 0.818 \\
\hline $\begin{array}{l}\text { To know more about the political and } \\
\text { social environment }\end{array}$ & $3.76(1.35)$ & 0.766 & & & 0.753 \\
\hline To gain a sense of accomplishment & $3.74(1.35)$ & 0.742 & & & 0.692 \\
\hline To see celebrities & $3.68(1.42)$ & 0.712 & & & 0.737 \\
\hline To understand more about myself & $3.92(1.24)$ & 0.689 & & & 0.746 \\
\hline To meet new and varied people & $3.93(1.2)$ & 0.672 & & & 0.708 \\
\hline To Shop & $3.96(1.19)$ & 0.635 & & & 0.755 \\
\hline To visit the cultural and heritage sites & $4.06(1.14)$ & 0.635 & & & 0.719 \\
\hline $\begin{array}{l}\text { To visit the places I saw on TV and/or } \\
\text { movies }\end{array}$ & $4.19(1.03)$ & 0.584 & & & 0.663 \\
\hline To be free to act the way I feel & $4.09(1.12)$ & 0.561 & & & 0.663 \\
\hline Novelty & & & & & 0.769 \\
\hline $\begin{array}{l}\text { To experience the local conditions and } \\
\text { social customs of the destination }\end{array}$ & $4.49(0.82)$ & & 0.844 & & 0.671 \\
\hline $\begin{array}{l}\text { To enjoy the natural scenery of the } \\
\text { destination }\end{array}$ & $4.51(0.78)$ & & 0.782 & & 0.749 \\
\hline To experience culture and conventions & $4.32(0.92)$ & & 0.725 & & 0.664 \\
\hline To experience something different & $4.53(0.73)$ & & 0.706 & & 0.687 \\
\hline To Feel the special atmosphere of the & $4.28(0.99)$ & & 0.622 & & 0.752 \\
\hline
\end{tabular}


destination

To visit the places I have read from books $\quad 4.08(1.158)$

0.617

0.752

Escape and relaxation

0.764

To be away from daily routine

$4.23(1.13)$

0.799

0.74

To release my work/study pressure

4.39(0.88)

0.783

0.68

To find a place to have a rest

4.1(1.12)

0.668

0.696

To be away from interpersonal relationship

(family, friends, colleague...)

$3.75(1.42)$

0.597

0.556

To have fun or be entertained

$4.26(0.99)$

0.549

0.711

To visit the places I learned about on social media

$4.26(0.91)$

0.509

0.711

Eigenvalue

$\%$ of Variance

Reliability coefficient
7.311

29.243

0.882
5.412

4.915

Total

$21.647 \quad 19.662$

70.552

Note: $\mathrm{KMO}=0.955$; Bartlett's Test of Sphericity: 6372.728

\subsection{Relationship between tourism motivation and social variables}

In order to answer the research questions 2, 3 and 4, related variables and factors are analysed.

\subsubsection{The relationship between the influence of Chinese One-child policy and Chinese post 90s generation's travelling abroad}

Firstly, as can be seen from Table 4.6, people's perception about whether the onlychild policy is important to travel motivation or not are negatively correlated with the three factors, and the correlation coefficients to each factor are $-0.299,-0.277$, and 0.341 respectively $(\mathrm{p}=0.000)$. This means that the perceived importance of the onlychild policy is inclined, and the tourism motivations decrease. There is a significantly negative relationship between the one-child policy and travel motivation. However, the causal relations of these two variables are not studied. And it should be pointed out that $78 \%$ of samples are the only child. Therefore, the connection between the one-child policy and tourism motivation needs further investigation in future research. 
Table 4.6 Correlations of tourism motivation with the only-child policy, social media and education

\begin{tabular}{|c|c|c|c|c|}
\hline & & $\begin{array}{l}\text { Factor1 } \\
\text { (Self-development and } \\
\text { relationship) }\end{array}$ & $\begin{array}{l}\text { Factor } 2 \\
\text { ( Novelty) }\end{array}$ & $\begin{array}{c}\text { Factor } 3 \\
\text { (Escape and relaxation) }\end{array}$ \\
\hline \multirow[t]{2}{*}{ Only child } & $\begin{array}{c}\text { Pearson } \\
\text { Correlation }\end{array}$ & $-0.299 * *$ & $-0.277 * *$ & $-0.341 * *$ \\
\hline & Sig. (2-tailed) & 0.000 & 0.000 & 0.000 \\
\hline \multirow[t]{2}{*}{$\begin{array}{l}\text { Social } \\
\text { media }\end{array}$} & $\begin{array}{c}\text { Pearson } \\
\text { Correlation }\end{array}$ & $0.779 * *$ & $0.718 * *$ & $0.812 * *$ \\
\hline & Sig. (2-tailed) & 0.000 & 0.000 & 0.000 \\
\hline \multirow[t]{2}{*}{ Education } & $\begin{array}{c}\text { Pearson } \\
\text { Correlation }\end{array}$ & $0.863 * *$ & $0.684 * *$ & $0.712 * *$ \\
\hline & Sig. (2-tailed) & 0.000 & 0.000 & 0.000 \\
\hline
\end{tabular}

Note: $* * \mathrm{p}<.005 ; \mathrm{N}=264$

\subsubsection{The relationship between media and the post-90s generation's travelling abroad in China}

Secondly, as shown in Table 4.6, the coefficients of the correlation between tourists' perception of social media's importance on their motivation and the three motivational factors are $0.779,0.718$ and 0.812 respectively $(p=0.000)$, indicating a significantly positive relationship. In other words, the more important that people think social media is for their motivation for travelling abroad, the more related the factor to tourism motivation. Also, from Table 4.4, it can be seen that $55 \%$ of the respondents choose social media to get travel information, indicating that social media is considered by many travellers as an indispensable platform for acquiring travel information. And $31.8 \%$ of the respondents choose TV, which means mass media also plays an important role in getting travel information.

To sum up, it can be concluded that there is a significant relationship between the impact of Chinese media and tourism motivation. In addition, the correlation coefficients between tourists' perception of social media's importance to their motivation and factor 3 (Escape and relaxation) is 0.812, which is the highest among the three motivational factors. Hence, it is considered that the more important that people think social media is for their motivation for travelling abroad, the higher the 
level of tourism motivation (Escape and relaxation) they have. This positive relationship is the most significant compared with other relationship between the other two motivational factors and social media.

\subsubsection{The relationship between education level and the motivation of the Chinese post-90s generation for travelling abroad}

Thirdly, it shows in Table 4.6 that the correlation coefficients of people's perception of education's importance to tourism motivation and three motivational factors are $0.863,0.684,0.712$ respectively $(\mathrm{p}=0.000)$. This means that the more important people think that education is to their motivation for travelling abroad, the more the factor is related to tourism motivation. As a result, it can be concluded that there is a significantly positive relationship between education and tourism motivation. In addition, Table 6 shows that the correlation coefficient of people's perception of education's importance to tourism motivation and factor 1 (Self-development and relationship) is the highest among the three motivational factors; therefore, it is considered that the higher the tourists' education level, the higher the level of tourism motivation (Self-development and relationship), and this positive relationship is the most significant compared with the relationships between other two motivational factors and education.

Also, from Table 4.7, the One-way ANOVA result indicates that people with different degrees of education have a $\mathrm{P}$ value of 0.000 in factor 1 (Self-development and relationship). It is considered that people with different education levels have significant differences in factor 1 (Self-development and relationship). At the same time, people with different degrees of education have a $\mathrm{P}$ value of 0.000 in factor 2 (Novelty) and factor 3 (Escape and relaxation) as well. Therefore, people with different degrees of education also have significant differences in factor 2 (Novelty) and factor 3 (Escape and relaxation). And the post-hoc test is also carried out to explore the significance of the difference between different degrees of education and three influential factors. It can be seen from Table 4.8 that in the three motivational factors, the significance of the Undergraduate degree is less than that of the Master degree and $\mathrm{PhD}$. When the responder has a master's degree or $\mathrm{PhD}$, the differences are more significant than the situation when people have undergraduate degrees. Meanwhile, from demographics, most respondents are undergraduate degrees and 
above. Respondents with master's degrees (51.5\%) are even more than those with undergraduate degrees (46.2\%), and these participants reflect the high motivational level. These results can also help to infer the positive relationship between tourism motivation and education level.

Table 4.7 One-way ANOVA and post-hoc result: Education level and motivational factors

\begin{tabular}{|c|c|c|c|c|c|c|c|}
\hline & & $\mathrm{N}$ & Mean & $\begin{array}{c}\text { Std. } \\
\text { Deviation }\end{array}$ & $\mathrm{F}$ & $P$ & LSD \\
\hline Factor 1 & Below high school (A) & 3 & 2.939 & .458 & 60.535 & 0.000 & $\mathrm{~A}<\mathrm{C}$ \\
\hline \multicolumn{7}{|c|}{ development degree(B) } & $\mathrm{B}<\mathrm{C}, \mathrm{D}$ \\
\hline \multirow[t]{2}{*}{ relationship) } & Master's degree $(\mathrm{C})$ & 136 & 4.487 & .924 & & & \\
\hline & $\mathrm{PhD}(\mathrm{D})$ & 3 & 5.000 & .000 & & & \\
\hline Factor 2 & Below high school(A) & 3 & 4.222 & .509 & 34.853 & 0.000 & $\mathrm{~B}<\mathrm{C}, \mathrm{D}$ \\
\hline \multirow[t]{3}{*}{ (Novelty) } & $\begin{array}{l}\text { Undergraduate } \\
\text { degree(B) }\end{array}$ & 122 & 3.944 & .716 & & & \\
\hline & Master's degree(C) & 136 & 4.735 & .549 & & & \\
\hline & $\mathrm{PhD}(\mathrm{D})$ & 3 & 5.000 & .000 & & & \\
\hline Factor 3 & Below high school(A) & 3 & 3.7778 & .585 & 33.547 & 0.000 & $\mathrm{~A}<\mathrm{D}$ \\
\hline \multirow[t]{3}{*}{$\begin{array}{l}\text { (Escape and } \\
\text { relaxation) }\end{array}$} & $\begin{array}{l}\text { Undergraduate } \\
\text { degree(B) }\end{array}$ & 122 & 3.6721 & .722 & & & $\mathrm{~B}<\mathrm{C}, \mathrm{D}$ \\
\hline & Master's degree(C) & 136 & 4.5956 & .792 & & & \\
\hline & $\mathrm{PhD}(\mathrm{D})$ & 3 & 5.0000 & .000 & & & \\
\hline
\end{tabular}

Note: Simplify Below high school to A, Undergraduate degree to B, Master's degree to C, PhD to D.

As the analysis above, the research question 2, 3, 4 are answered respectively.

\subsection{Mean comparisons by genders}

In order to verify the difference in tourism motivation between genders, a T-test was conducted (see Table 4. 8). It can be seen that the P value of the independent sample T-test for males and females in factor 1 is 0.000 , less than 0.05 . Therefore, it is considered that males and females have significant differences in factor 1 (Selfdevelopment and relationship). Similarly, males and females have significant differences in factor 2 (Novelty) and factor 3 (Escape and relaxation), because their p- 
values are 0.000 as well. In addition, the males' mean value is higher than that of the females corresponding to the three factors. Therefore, the difference in males is considered to be significantly higher than that in females.

Table 4.8 T-test result: Differences between men and women

\begin{tabular}{cccccc}
\hline & Gender & Mean & Std. Deviation & T & P \\
\hline $\begin{array}{c}\text { Factor 1 } \\
\begin{array}{c}\text { Self- } \\
\text { development } \\
\text { and } \\
\text { relationship) }\end{array}\end{array}$ & Male & 4.611 & .836 & 13.635 & 0.000 \\
$\begin{array}{c}\text { Factor 2 } \\
\text { (Novelty) }\end{array}$ & Male & 3.213 & .824 & & \\
Factor 3 & Male & 4.600 & .522 & 10.103 & 0.000 \\
$\begin{array}{c}\text { (Escape and } \\
\text { relaxation) }\end{array}$ & Female & 3.753 & .765 & & \\
\hline
\end{tabular}

Note: $* * p<0.005 ; \mathrm{N}=264$

\subsection{The open-ended question analysis}

The respondents' responses to the open-ended question about what factors they think influence their motivation to travel abroad are analysed. The responses are varied, but there are still several keywords with high mentions, indicating that many respondents are affected by these factors. The keywords with the highest mentions are money and time, since $65 \%$ of the respondents mentioned both money and time in their answers. It reflects that for China's post-90s generation, the arrangement of time and economic conditions are the important factors influencing their tourism motivation. The second most frequently mentioned key word is mood. More than half of the respondents who mentioned mood said they felt down after a bad experience and wanted to travel to change their mood. Some respondents also stated that they would like to travel because they felt happy at a certain time. About $35 \%$ of the respondents said their mood affected their motivation to travel overseas. This shows that for many post-90s people, their mood condition is an important consideration for their motivation. Meanwhile, the third key words most frequently mentioned are family and friends. The respondents mentioned two different aspects of family and friends. The first one 
is the recommendation of family and friends, which can be interpreted as that they attach great importance to the recommendations and suggestions of travel destinations or tourism products from family or friends. The second is visiting relatives and friends. Some respondents clarified when referring to family members and friends that settled abroad somewhere, they would visit them in the local tourism, and stay in the home of their family members or friends, thus saving a large part of the cost. Therefore, family and friends settling somewhere in a foreign country can be one of the factors influencing their motivation to travel. 


\section{Chapter 5 Discussions}

The results include important findings that can achieve the research aim of this study, i.e., to explore what factors influence and reflect on the Chinese post-90s' tourism motivations based on China's social background.

First, the results show that there are three main factors affecting the Chinese post-90s' tourism motivations of travelling abroad, which are self-development and relationship; novelty; escape and relaxation. The self-development motivation can be explained as an individual seeking personal growth, eager to learn and interact with the destination culture and its community (Calantone \& Johar, 1984; Crompton, 1979). The motivation for seeking and relationship shows the individual's desire to achieve human interaction and social interaction through travel (Tinsley, Rarrett, \& Kass, 1977). Self-development and relationship are one of the important motivational factors, which mainly reflect the developmental motivations of Chinese youth in two aspects. First, the youth have the needs for the expansion of their knowledge, the pursuit of broad vision, and the desire to experience cultural differences. Local customs, history and art help to enrich their knowledge and experience. One of their main values of travel is to become an experienced person who understands different things more deeply, experience differences and seek self-improvement form travelling abroad (Jiang, Noel, \& Peiyi, 2015). The second is the pursuit of building more diverse interpersonal relationships; the youth hope to get new interpersonal relationships through travel. And they seek diversity and novelty related to tourism (San Martín \& Rodríguez del Bosque, 2008).

It is particularly important to note that among these factors, novelty is shown to be the most important motivational factor. Novelty means that when a person is in a familiar environment for a long time, he or she gets tired of this environment and is eager to seek excitement through complex and un-coordinated situations (Crotts, 1993). The post-90s people are extremely eager to seek something new, hoping to have new, different things. At the same time, the results show that Chinese youth hope to feel the unique atmosphere of the destination through travelling, which is different from daily life, and to experience the beautiful natural scenery. Tourism motivation can be predicted by socio-demographic characteristics such as age, education level and income of the tourists. In terms of age (Jönsson \& Devonish, 2008), some studies have found that the elderly are generally more 
susceptible to novelty (Jang \& Feng, 2007). Luo and Deng (2008) conducted an investigation on Chinese tourists, further showing a negative correlation between age and motivation. This result indicates that young tourists are more inclined to pursue novelty. Moreover, Kim et al. (2008) point out that young people are more enthusiastic about pursuing novelty than older people. The study also demonstrates the strong desire for novelty among young Chinese, and further shows that novelty is the most important factor affecting their tourism motivation.

Thirdly, some of the post-90s people choose overseas travel to escape from daily life and get opportunities to relax. In particular, the results illustrate that many post-90s people choose to travel abroad because they want to relieve the pressure of work and life through travel. On the one hand, in the modern China, due to the economic development of the society, the competition is becoming more intense; hence a lot of the post-90s people are under great pressure of life and study; on the other hand, many young travellers choose to reduce their stress by travelling rather than other entertainment activities, illustrating that travel in their perception is an important way of reducing pressure. It can be said that the pursuit of novelty is the need to pursue stimulation, and the motivation to seek evasion can be interpreted as the need to get rid of excessive stimulation (Iso-Ahola, 1982). The study by Mannell and IsoAhola (1987) suggests that escaping from daily stress is the main motivation for leisure travel, and the studies by different researchers also proved this finding. In addition, it is found that escaping from daily stress and gaining a relaxing experience through tourism are also one of the main factors affecting the motivation of Chinese youth tourists.

The motivational factors including novelty, escape/relaxation, relationships and selfdevelopment can be seen as the basis and core of all travel motivation (Pearce \& Lee, 2005). Under China's social background, the main factors affecting travel motivation of Chinese post-90s are also included in the core motivational factors. The travel motivation model of Chinese youth can be described as a combined motivation based on novelty, escape/relaxation, relationships and self-development.

However, compared with the existing findings of the motivations of Chinese tourists, the post-90s people present different characteristics. China's social culture shapes the unique values and characteristics of Chinese tourists, including the concepts of face ("mian zi") and relationship ("guan xi”) (Anson, Alice, Lewis, Karen, \& Shuwen, 2018). Studies have shown that these two traditional Chinese values have profoundly affected the formation of behaviours and motivations of Chinese tourists (Li \& Cai, 2012). Face (“mian zi”) is very 
important to the Chinese because it represents a person's social status, allowing them to feel self-esteem and prestige, as well as the power they have. The most direct manifestation of face is wealth and spending power ( $\mathrm{Li} \& \mathrm{Su}, 2007)$. Pearce (2013) points out in his research that Chinese tourists like to travel to famous scenic spots, buy things, and then share the experience to prove to those around them that they have the ability and economic conditions to gain reputation. This desire to gain reputation is mostly influenced by their family and friends. The common phenomenon of organizations among Chinese tourists focuses on explaining the motivation factors of social influence, indicating that tourists are either encouraged by family or friends or want to prove their ability to them. The concept of "guan xi" further explains people's desire to show off their wealth by travelling. In China, "guan xi" refers to the social relationship established with people of similar social status and background (Li \& Cai, 2012). Therefore, in this case, "guan xi" is usually the main motivation driving the Chinese people to travel (Anson, Alice, Lewis, Karen, \& Shuwen, 2018).

However, in contrast, the results of this study show that relationship and self-development are the least influential of the three main factors. It proves that for Chinese young people, the main purpose of their travel is not to build some social connections or gain social reputation, but to pursue new things and seek stimulation. It can also be proved that China's post-90s people are a generation different from other age groups, especially in their thinking patterns and behaviours. Therefore, this mode of thinking certainly affects their travel motives. From the root, their most important motivational factors are different from those of most Chinese tourists because the current social changes in China affect their thinking mode and shape their characteristics. This study shows that the most important factors always vary with the social, demographic, and individual backgrounds of tourists.

Additionally, in this study, some important findings of the relationships between Chinese youth travellers' motivation and China's social variables are discovered, which contribute to carrying out the existing research on youth tourism in China and provide guidance and direction for the potential tourism market.

China's media do have a positive and significant relationship with the tourism motivation of China's post-90s generation; in other words, the media have a significant influence on the tourism motivation of Chinese youth. In China, under the continued rapid development of economy, science and technology, Chinese media is evolving, with growing influences; 
especially the influence on the youth in China continues to increase, and the media gradually play an important role in their daily life. Young people use the media not only as a form of entertainment, but also as a form of social interaction. They use social media platforms to express their social ideas and show their lives including travel experiences (Tricia, 2013). This enables them to learn travel-related information from various media, especially when social media is frequently used by them. They can always get travel information and travel trends shared by others, which motivate them to travel. China has more e-commerce activities on its Internet platforms than any other countries in the world today. And its social media environment has a huge impact on consumer behaviour. Due to the influence of daily social media, the Chinese people are interacting with an increasing number of foreigners living in China, sharing the stories after travelling overseas.

Secondly, there is indeed a positive and significant relationship between education and the tourism motivation of China's post-90s generation. It indicates that education has a positive impact on the tourism motivation of Chinese youth. It can be considered that the youth's willingness to travel will increase with the continuous improvement of their education level. With the upgrading of domestic market consumption and adjustment of Chinese population structure, the share of education consumption in the total household consumption is growing, which makes China's education market maintain a positive development trend. Also, the Chinese people's education level has been significantly improved, especially the younger generation (Bie \& Yi, 2014). Also, with the opening up of China to the outside world, the quality of education in China has been continuously improved, and educated people are more exposed to foreign knowledge and culture. Higher education means that young people can receive more knowledge and information, such as cultural and historical content, enhancing their understanding of cultural diversity. Also, education, to a certain extent, can encourage the youth to pursue new knowledge, experience differences, and acquire new knowledge through travelling (Chen, 2004). Therefore, when the educational background of the post-90s generation in China is generally improved, there is a huge potential of China's youth tourism market. Tleuberdinova and Kikbayeva (2016) highlighted the important role of education in youth tourism in their research. For many young people, youth tourism is not only for fun, but also for education. Travel is a way to better understand the world and broaden their visions. According to the results of this study, Chinese youth want to know different things. Travel is also regarded as a way to acquire different experiences and knowledge. The 
progress of China's education gives young people more desire to acquire knowledge through travel, such as the history and culture of the destination.

Also, in general, the demographic characteristics of this study show consistency with those of the Chinese post-90s. First, as mentioned above, the average academic qualifications in Chinese post-90s are generally high. This shows that they have a higher level of literacy, a better ability to understanding, and more needs for knowledge. Therefore, travellers including the youth usually have a higher demand for the value and connotation of tourism products. Secondly, the income of China's post-90s generation is at the middle level in China, generally not very high.

Targeting the special age group, it is very important to have accurate consumer information. In terms of Chinese youth tourism market, the characteristics of China's post-90s generation such as high education level and middle-level income should be taken into account to improve and refine the strategic content. As the target is young Chinese travellers, in the promotion of destinations, the operators of tourism products should first focus on the uniqueness and novelty of products to meet their demands for new things. In addition, since young travellers hope to reduce pressure through travel, it is necessary to conduct more detailed investigations and understand their considerations such as what kind of tourism products can let them release stress, thus meeting their needs in the design of tourism products. Also, tourism motivations of Chinese young travellers, such as eagerness to learn cultural and experience differences through travelling abroad, can be turned into a marketing plan. Adding information about the cultural value of the relevant destination will greatly improve the effectiveness of tourism marketing planning and strategies (Mimi, Hanqin, Honggen \& Yong, 2015). Destination marketers can emphasize the possibility of realizing value through destination travel, and present the uniqueness of the destination culture in their advertising campaigns, thereby evoking the youth's travel motivation. In addition, according to the travel experience of young travellers obtained from the research, they prefer economical travel. They always control the cost of travel, and mainly choose budget hotels and youth hostels. Therefore, tourism marketers and managers should promote tourism products according to these characteristics, such as emphasizing the affordability.

Moreover, this study highlights that since the social environment is constantly changing, tourism marketers need to keep up with the changes and trends and improve their understanding of young travellers. Cha et al. (1995) argue that the regular investigation of the 
same market is helpful to capture trends more effectively, thereby adjusting advertising information and then matching motivation to destination tourism and physical facilities. In particular, in a country with rapid economic growth such as China, variations in the demographic characteristics are brought about by changes in the social environment rapidly, especially for young consumers. Hence it is necessary to pay attention to the trend of the youth to cater for young travellers' preferences and needs. In view of the huge influence of media on young travellers, tourism marketers can greatly increase young travellers' interest in tourism products by using media to publicize and get in line with popular trends.

Additionally, the answers to the open-ended questions illustrate that many Chinese young people also consider time and money as factors affecting their motivation to travel. This phenomenon can also be regarded as the characteristics of traditional youth tourism. In western studies on the characteristics of youth tourism, it is emphasized that when young people travel, they usually have strict control over travel expenditure, which is reflected in their choice of hotel accommodation. They prefer budget hotels or youth hotels rather than luxury hotels (Horak \& Weber, 2000). This theory is consistent with the finding of this research. For Chinese youth, most of the respondents choose budget hotels or youth hostels; while only a small proportion choose luxury hotels. At the same time, economical home-stay is also a new choice for Chinese youth when travelling. This reflects that Chinese youth choose a more economical way to travel.

In this study, the respondents frequently mentioned time and money. This shows that the time budget is also very important for Chinese youth. According to the characteristics of youth tourism described in previous studies, time arrangement is an important characteristic of youth tourism. When young people travel, their travel time is longer than that of other age groups, because they want to create opportunities to communicate with other travellers (Horak \& Weber, 2000). Although their preference for time arrangement is not deeply analysed, it still reflects that Chinese youth pay more attention to the time budget. This is also in line with the characteristics of youth tourism in western discussions. 


\section{Chapter 6 Conclusion}

\subsection{Summary of research findings}

This study targets one specific age group, China's post-90s generation, which is the youth that grows up under the development of China. It aims to explore and understand the important tourism motivations of Chinese youth. This study has various important findings. First and foremost, the study identifies the factors influencing the motivations of China's post-90s generation for travelling abroad, including self-development and relationship, novelty, as well as escape and relaxation. Secondly, this study proves that the changes in Chinese society in various ways have a great influence on China's post-90s, and play an important role in their motivation for travelling abroad. The result of this study shows that there is a significant relationship between China's One-child policy and the motivations of the post-90s for travelling abroad. Secondly, this study shows that there is a significant and positive relationship between the Chinese media and the motivations of the post-90s for travelling abroad. Also, the education level has a significant and positive relationship with the motivations of the post-90s for travelling abroad. Overall, these findings mentioned above can fill some gaps in the research on the motivation of Chinese youth tourism and provide new ideas for China's potential youth tourism market.

\subsection{Contribution}

At the present stage, there are not many studies on tourism of Chinese youth in academic fields. This study provides a reference, improves the definition of Chinese youth, and emphasizes the particularity of China's post-90s generation as Chinese youth. And through this study, it can be seen that the social variables in this special age group have significant impacts on tourism motivation. Therefore, social environment and socio-demographics should be considered during the study on importantly effective factors of tourism motivation. The research results prove the basic theory proposed by previous studies; in other words, the motivational factors of tourism basically include escape/relax, novelty, relationships and selfdevelopment. This study confirms the results and further proves that they are still regarded as the main factors affecting tourism motivation as the target group is Chinese youth. It can be further speculated that these core motivational factors may not change much despite the differences in travel experiences and demographic characteristics of travellers. 
Moreover, this study also shows more specific findings of Chinese youth. Nowadays, Chinese youth start to travel much earlier than their parents who had to wait after graduating from college. Today's Chinese young people have started to travel in high schools by modern transportation. Information is inseparable and closely related to the psychosocial characteristics of Chinese youth: (1) They are lively, curious, and adventurous, the so-called new-born calves who are not afraid of tigers, favouring travelling abroad, especially adventurous tourism. (2) They are physically strong and energetic. Compared with their predecessors, today's Chinese youth live in a peaceful era when the national economy is developing at a rapid pace, and their good and healthy conditions have laid a solid guarantee for travelling. (3) They want to gain more knowledge. In the 21st century, China's survival competition is becoming increasingly fiercer, reflected in two major aspects of education and job hunting for Chinese youth. Travelling is one of the ways to broaden their horizons and increase knowledge, which hence gets welcomed by Chinese young people. (4) They are concerned about the quality of life. Chinese youth accept new things quickly and have a more pioneering role in lifestyle. Tourism is more acceptable to Chinese youth as a new way of life and a way to promote interaction with different people. Also, the beautiful blue sky and pollution-free tourism products are more popular among Chinese youth.

This study fills the gap in the research of Chinese youth tourism in the academic field by studying the tourism motivations of China's post-90s generation. It further shows that novelty is the most important factor among the three main factors influencing the tourism motivation of China's post-90s generation. Compared with other types of tourists and other age groups, China's post-90s generation want to pursue new things and new stimuli, which exceeds their desire to get relax, escape from the daily life, build new relationships or get self-improvement through travel. Also, their pursuit of novelty during tourism is significant. These findings provide an important reference for studying the travel behaviour and travel patterns of China's post-90s generation.

From the practical perspective, as tourism motivation is the core interest of tourism marketers and managers (Jiang, Noel, \& Peiyi, 2015), studying the motivational characteristics associated with the particular population like the young generation will help them to develop effective and targeted marketing programs to attract young travellers (Jang \& Wu, 2006). It can also help travel marketers and managers develop strategies to improve the youth tourism market by marketing and improving specific products or services, as well as increasing the overall satisfaction of Chinese young visitors. It also provides a new idea for the tourism 
industry, helping to effectively serve a specific market. Destination managers are advised to obtain complete and accurate information about the individuals that make up each market segment. Tourism marketers should strengthen publicity and promotions. This study also emphasizes the importance of the media to youth tourism. Therefore, attention should be paid to the Chinese media, to improve the online promotion. And considering the interests of young people, books, movies, TV shows or others can be good media. For example, some TV shows or movie series shot all over the world display the local culture and landscape, which can well stimulate the travel interest of Chinese youth. In particular, Chinese youth often use social media to share travel experiences. Therefore, making good use of social media is an important strategy for tourism marketers. WeChat is the most popular social media platform in China and widely used by the post-90s generation. Another popular platform is Weibo, which offers a good photo-sharing function. These social media applications are often used by Chinese youth to get specific content and comments. A large number of Chinese youth always check new information through these social media, believing they will help make an informed decision when planning the next vacation. Therefore, the key for travel marketers to make good use of social media is to attract consumers with interesting topics or stories related to travel products. They can also use blogs or messages to arouse the interests of viewers, encourage them to spread and share the information with their family, friends or colleagues.

Secondly, according to the characteristics of youth tourism, the most realistic way to develop the youth tourism market is to reduce the cost. Therefore, the government and tourism departments should give more appropriate discounts, such as tickets and accommodation, to attract young tourists. At present, other industries in China have special promotion activities and preferential measures for youth, achieving a good effect. If tourism enterprises take similar measures, the market will become more promising.

Also, tourism managers and marketers should consider launching a variety of distinctive tourism products to meet the needs of young tourists. Based on the unique characteristics of Chinese youth, the following tourism products deserve more attention: (1) natural adventure tourism: this is in line with the desire of Chinese young people to return to nature and to see the scenery of nature; (2) Sports tourism: Chinese young people are active, like to experience stimuli, most of whom love sports; (3) Culture educational tourism: combining culture and education with tourism can obtain high-level spiritual enjoyment, which is in line with young people's demand for acquiring knowledge, seeking difference and diversity. 
It can be seen clearly that the values of youth tourism lie in its unique characteristics of young people who have adventure desire to contact with the contemporaries, broaden visions and discover new culture; the more the better, the longer the better. Also, Chinese youth are more likely to experience different things. Thus, young travellers to global travel destination have a special value.

To sum up, according to the characteristics of Chinese youth, to develop targeted tourism products and open tourism resources can more effectively promote the Chinese youth tourism market, which will contribute to the in-depth development of tourism.

\subsection{Limitation and future study}

Despite the contribution to the existing literature with new findings, some limitations still exist. The research target is China's post-90s generation, with a large population. Due to the limitation of time, a large number of samples cannot be obtained in a short time; therefore, the number of samples taken during this survey is limited. In addition, due to the geographical characteristics of China, it is difficult to sample in every city in a limited time. The samples in this study are from some representative cities in China. Therefore, the results obtained from the survey can only reflect the situation of some post-90s in China, reducing the accuracy of the research results. In future studies, it is better to obtain a large number of samples when studying China's post-90s generation, so as to obtain more accurate results and reduce errors.

As China's post-90s generation is becoming a new labour force leading the Chinese society, they are gradually moving towards the mainstream tourism market and becoming more important in the tourism market. However, until now, the study on the Chinese post-90s generation as a tourism motivation research object is very limited. Therefore, for future study, it is needed to do more research on tourism motivations of the objects in a specific age group combined with the social background. For example, this study finds a significantly negative relationship between China's special political policy (one-child policy) with the tourism motivation of Chinese teenagers. However, it should be further discussed in future.

Overall, the social background of China's post-90s generation is an important consideration for the study of tourism motivation. This study provides a new idea for future relevant studies, but it is still needed to conduct further research and supplement existing theories, thereby contributing to the potential tourism market. 


\section{References}

Anson, T. H. Ma., Alice, S. Y. Chow., Lewis, T. O. Cheung., Karen, M. Y. Lee, \& Shuwen Liu. (2018). Impacts of tourists' sociodemographic Characteristics on the travel motivation and satisfaction: The case of protected areas in South China. Sustainability, 10(10), 3388.

Albayrak, T., \& Caber, M. (2018). Examining the relationship between tourist motivation and satisfaction by two competing methods. Tourism Management, 69, 201-213.

Bright, A. D. (2008). Motivations, attitudes, and beliefs. In H. Oh, \& A. Pizam (Ed.), Handbook of Hospitality Marketing Management (pp. 239-266). Oxford: Butterworth Heinemann.

Burns P, Holden A. (1995). Tourism: A new perspective. Prentice Hall: London.

Bywater, M. (1993). The youth and student travel market. EIU Travel and Tourism Analyst 3, $35-50$.

Bieger, T., \& Laesser, C. (2002). Market segmentation by motivation: The case of Switzerland. J. Travel Res, 41, 68-76.

Crompton J. L. (1979). Motivations for pleasure vacation. Annals of Tourism Research 6(4), $408-424$.

Crotts, J. C. (1993). Personality correlates of the novelty seeking drive. Journal of 26 Hospitality \& Leisure Marketing, 1(3), 7-29.

Castaňo, J. M., Moreno, A., García, S., \& Crego, A. (2003). Aproximación psicosocial a la motivación turística: Variables implicadas en la elección de Madrid como destino. Estudios Turísticos, 158(3), 5-41.

Cha, S., McCleary, K., \& Uysal, M. (1995). Travel motivations of Japanese overseas travelers: a factor-cluster segmentation approach. Journal of Travel Research, 34(1), 33-39. 
Calantone, R. J., \& J. S. Johar (1984). Seasonal segmentation using benefit segmentation Framework. Journal of Travel Research, 23 (2), 14-24.

China Post-90s Online Users Insights. Retrieved August 18, 2015 from https://www.chinainternetwatch.com/15530/post-90s-consumption-power-china/

Cvetković, Milena,\& Sara Jovanović. (2018). The Chinese tourist- a chance for development of cultural tourism. Quaestus, 12(2), 69-76.

Dann, G. M. S. (1977). Anomie, ego-enhancement and tourism. Annals of Tourism Research, 4(4), 184-194.

Destination New. (2008, May 8). International youth leisure market. Retrieved March 17, 2014, from http://www.destinationnsw.com.au/wp-content/uploads/2014/03/Youth-Fact$\underline{\text { Sheet.pdf?x15361 }}$

Demeter, T., \& Bratucu, G. (2014). Typologies of youth tourism. Bulletin of the Transilvania University of Brasov. Economic Sciences. Series V, 7(1), 115-122.

Ding, Xin, Jian Niu., \& Yanhui Han. (2010). Research on distance education development in China. British Journal of Educational Technology, 41(4), 582-92.

Dun-rong, Bie., \& Meng-chun,Yi. (2014). The context of higher education development and policy response in China, Studies in Higher Education, 39(8), 1499-1510.

Ewert, A. (1989). Outdoor adventure pursuits: Foundation, models and theories. New York: Publishing Horizons.

Fluker, M. R., \& Turner, L. W. (2000). Needs, motivations, and expectations of a commercial whitewater rafting experience, Journal of Travel Research, 38(3), 380-389.

Haigh, R. (1995). Backpackers in Australia. Bureau of Tourism Research, 20, 12-34. 
Hongmei,Qiu. (2012). A brief analysis of the uniqueness of life attitude of post-90s youth and the reasons for its formation. Market modernization, 20(2), 312-312.

Hsu, C. H. C., Cai, L. A., \& Li, M. (2010). Expectation, motivation, and attitude: A tourist behavioral model. Journal of Travel Research, 49(3), 282-296.

Horak, S., \& Weber, S. (2000). Youth tourism in Europe: Problems and prospects. Tourism Recreation Research, 25(3), 37-44.

Inglehart, R. (1977). The silent revolution: Changing values and political styles among Western publics, Princeton: NJ.

International council of youth tourism. (1991). Indicators, trends and forecasts- youth market. World Travel and Tourism Review 1(2), 143-144.

Iso-Ahola, S. E. (1982). Toward a social psychological theory of tourism motivation: A rejoinder. Annals of Tourism Research, 9(2), 256-262.

Jensen, J. M. (2011). The relationships between socio-demographic variables, travel motivations, and subsequent choice of vacation. 2nd International Conference on Economics, Business and Management, 22, 37-44.

Junsen. Zhang, (2017). The evolution of China's one-child policy and its effects on family outcomes. Journal of Economic Perspectives. 31(1), 141-60.

Jönsson, C., \& Devonish, D. (2008). Does nationality, gender, and age affect travel motivation? A case of visitors to the Caribbean island of Barbados. J. Travel Tour. Mark. 2(5), 398-408.

Jang, S., \& Feng, R. (2007). Temporal destination revisit intention: The effects of novelty seeking and satisfaction. Tourism Management, 28(2), 580-590. 
Jamal T, \& Lee J.H. (2003). Integrating micro and macro approaches to tourist motivations: toward an interdisciplinary theory. Tourism Analysis 8(1), 47-59.

Jang, S., \& Wu, C. (2006). Seniors' travel motivation and the influential factors: An examination of Taiwanese seniors. Tourism Management, 27(2), 306-316.

Jiang, S., Scott, N., \& Ding, P. (2015). Using means-end chain theory to explore travel motivation: an examination of Chinese outbound tourists. Journal of Vacation Marketing, 21(1), 87-100.

Kay, P. (2003). Consumer motivation in a tourism context: continuing the work of Maslow, Rokeach, Vroom, Deci, Haley and others. Paper presented at the ANZMAC 2003 Conference. University of South Australia, Adelaide, Australia.

Kelley-Quon, L. (2018). Surveys: Merging qualitative and quantitative research methods. Seminars in Pediatric Surgery, 27(6), 361-366.

Kim, S.S., Kim, M., Park, J., \& Guo, Y. (2008). Cave tourism: Tourists' characteristics, motivations to visit, and the segmentation of their behaviour. Asia Pac. J. Tour. Res. 1(3), 299-318.

Linh, N. T. K. (2015). Student and youth tourism: a case study from Vietnam. The Journal of developing areas, 49(5), 293-307.

Li, M., Cai, L.A. (2012). The effects of personal values on travel motivation and behavioral intention. J. Travel Res, 5(1), 473-487.

Lue, C., Crompton, J. L., \& Fesenmaier, D. (1993). Conceptualisation of multiple destination pleasure trips. Annals of Tourism Analysis, 20(2), 289-301.

Luo, Y., \& Deng, J. (2008). The new environmental paradigm and nature-based tourism motivation. J. Travel Res. 4(6), 392-402.

Li, J.J., \& Su, C. (2007). How face influences consumption. Int. J. Mark. Res, 4(9), 237-256. Li, M., Zhang, H., Xiao, H., \& Chen, Y. (2015). A grid-group analysis of tourism motivation. International Journal of tourism research, 17(1), 35-44.

MacCannell, D. (1976). The tourist: A new theory of the leisure class. Schocken: New York. 
Maslow, A. H. (1970). Motivation and personality. New York: Harper \& Row.

McClelland, D. C. (1955). Studies in motivation. New York: Appleton-Century-Crofts.

Moisă, C.O. (2010). Aspects of the youth travel demand. Annales Universitatis Apulensis Series Oeconomica, 12(2), 581.

Mook D. (1996). Motivation: the Organization of Action. Norton: New York.

Moscardo, G. (2011). Searching for well-being: Exploring change in tourist motivation. Tourism Recreation Research, 36(1), 15-26.

Murray, H. A. (1938). Explorations in personality. New York: Oxford University Press.

Moscardo, G. M., \& Pearce, P. L. (1986). Historical theme parks: an Australian experience in authenticity. Annals of Tourism Research, 13 (3), 467-794.

Neuman, W. (2011). Social research methods: Qualitative and quantitative approaches. Boston: Allyn \& Bacon.

Pearce, P. L. (1991). Dreamworld: A Report on Public Reactions to Dreamworld and Proposed Developments at Dreamworld. In A Report to Ernst and Young on Behalf 81 of the IOOF in Conjunction with Brian Dermott and Associates. Townsville, Australia: Department of Tourism, James Cook University

Pearce, P. L. (1988). The Ulysses factor: Evaluating visitors in tourist settings (recent research in psychology). New York, NY: Springer New York.

Pearce, D., \& Butler, R. (1993). Tourism research: Critiques and challenges in Douglas G. Pearce and Richard W. Butler(Ed.). In association with the International Academy for the Study of Tourism. London: Routledge.

Pearce, P. L., \& Caltabiano, M. L. (1983). Inferring travel motivation from travellers' experiences. Journal of Travel Research 22(2), 16-20.

Padurean, M., Nica, A., Hornoiu, R., \& Tanase, M. (2014). Trends in tourism consumption behaviourof the young generation. Calitatea, 15(5), 110.

Pearce, P. L., \& Lee, U. (2005). Developing the travel career approach to tourist motivation. Journal of Travel Research, 43(3), 226-237. 
Pearce, P. L., Wu, M.Y., \& Osmond, A. (2013). Puzzles in understanding Chinese tourist behaviour: Towards a triple-C gaze. Tour. Recreat. Res. 3(8), 145-157.

Rojek, C. (1995). Decentring leisure: Rethinking leisure theory. London: Sage.

Richards, G. (2007). New Horizons II: The Young Independent Traveller 2007. World Youth Student and Educational (WYSE) Travel Confederation. Retrieved from http://www.wysetc.org/Docs/New_HorizonsII.pdf

Ryan, C., \& Glendon, I. (1998). Application of leisure motivation scale to tourism. Annals of Tourism Research, 25(1), 169-184.

Richards, G., \& Wilson, J. C. (2003). Today's youth travelers, tomorrow's global nomads? New horizons in independent youth and student travel. Amsterdam: International Student Travel Confederation (ISTC), 2(1), 3.

Survey report on overseas tourism of Chinese tourists Retrieved April 15, 2017, from https://www.ipsos.com/sites/default/files/201707/CITM\%202017\%20Report\%20Chinese.pdf

Shoemaker, S. (1994). Segmenting the U.S. travel market according to benefits realized. Journal of Travel Research, 32(3), 8-21.

Shuguang Zhang. (2017, July 23). China's reform and macro-economy in the 1990s. The ideal of literature. Retrieved March 11, 2017, from https://www.92to.com/xuexi/2017/03$\underline{11 / 18498176 . h t m l}$

Sin, H. L. (2009). Volunteer tourism —-involve me and I will learn"? Annals of Tourism Research, 36(3), 480-501.

Surging News. (2018, June 17). China has made 3.7 trips per person, and those born in the 1990s are the most willing to spend money on travel. Retrieved June 1, 2018, from https://baijiahao.baidu.com/s?id=1589752939468424546\&wfr=spider\&for=pc

Snepenger, D., King, J., Marshall E., \& Uysal M. (2006). Modeling Iso- Ahola's motivation theory in the tourism context. Journal of Travel Research 45(2): 140-149. 
Simpson, G., \& Lord, B. (2015). Enhancing the reporting of quantitative research methods in Australian social work. Australian Social Work, 68(3), 1-9.

Sofield, T., \& Li, F.M.S. (2007). China: Ecotourism and cultural tourism, harmony or dissonance. Crit. Issues Ecotour. Underst. Complex Tour. Phenom, 368-385.

San Martín, H., \& Rodríguez del Bosque, I. A. (2008). Exploring the cognitive-affective nature of destination image and the role of psychological factors in its formation. Tourism Management, 29(2), 263-277.

Tomazos, K. (2010). Volunteer Tourism, An ambiguous phenomenon: An analysis of the demand and supply for the volunteer tourism market. Innovative Marketing, 6(4), 42-47.

Tomazos, K., \& Butler, R.W. (2009). Volunteer tourism: the new ecotourism? An International Journal of Tourism and Hospitality Research, 1(2), 25-38.

Tleuberdinova, A. T., \& Kikbayeva, A. K. (2016). Youth tourism in the studies of foreign authors and the socio-economic importance of youth tourism for the Republic of Kazakhstan. Education and Science without Borders, 7(14), 24-27.

UNESCO (1995). Policy Paper for Change and Development in Higher Education. Paris: UNESCO.

Wang N. (2000). Tourism and modernity: A sociological analysis. Pergamon: Oxford.

World Economic Forum. (2013, April 11). The travel \& tourism competitiveness report. Retrieved July 23, 2013, from the World Wide Web: http://www3.weforum.org/docs/WEFTT_Competitiveness_Report_2013.pdf

World Tourism Organization. (1991). International conference on youth tourism- final report. New Delhi, India: World Tourism Organization.

Wolfe, K., \& Hsu, C. H. C. (2004). An application of the social psychological model of tourism motivation. International Journal of Hospitality \& Tourism Administration, 5(1), 2947.

Woodside, A. J., \& L. W. Jacobs. (1985). Step two in benefit segmentation: Learning the benefits realised by major travel markets. Journal of Travel Research, 24(1), 7-13. 
Xu, Y., Li, X., \& Weaver, P. A. (2010). Examining the dimensions of travel behavior: A case of Chinese tourists visiting the United States. Tourism Analysis, 15(3), 367-379. 


\section{Appendix}

\section{Appendix A: Source of questions}

\begin{tabular}{|c|c|c|}
\hline & Questions & Source \\
\hline \multirow[t]{3}{*}{ Section1: Travel experience } & $\begin{array}{l}\text { How many times do you travel } \\
\text { abroad without your family per } \\
\text { year? }\end{array}$ & $\begin{array}{l}\text { Modified from Linh, } \\
\text { N.T.K.,2015 }\end{array}$ \\
\hline & $\begin{array}{l}\text { What is the average cost of your } \\
\text { abroad trip? }\end{array}$ & $\begin{array}{l}\text { Modified from Linh, N. T. } \\
\text { K.,2015 }\end{array}$ \\
\hline & $\begin{array}{l}\text { How many days do you usually } \\
\text { stay when you travel abroad? }\end{array}$ & $\begin{array}{l}\text { Modified from Linh, N. T. } \\
\text { K.,2015 }\end{array}$ \\
\hline \multirow[t]{8}{*}{$\begin{array}{l}\text { Section2: The motivation of } \\
\text { travelling abroad } \\
\text { (5-point Likert scale) }\end{array}$} & $\begin{array}{l}\text { (1)To experience something } \\
\text { different }\end{array}$ & $\begin{array}{l}\text { Modified from Li, Zhang, Xiao, } \\
\& \quad \text { Chen } \\
\text { Pearce, \& Lee, } 2005\end{array}$ \\
\hline & $\begin{array}{l}\text { (2) To experience the local } \\
\text { conditions and social customs } \\
\text { of the destination }\end{array}$ & \\
\hline & $\begin{array}{l}\text { (3) To enjoy the natural } \\
\text { scenery of the destination }\end{array}$ & \\
\hline & $\begin{array}{l}\text { (4) To visit places related to } \\
\text { my personal interests }\end{array}$ & \\
\hline & (5) To see celebrities & \\
\hline & $\begin{array}{l}\text { (6) To Feel the special } \\
\text { atmosphere of the destination }\end{array}$ & \\
\hline & $\begin{array}{l}\text { (7) To gain a sense of } \\
\text { accomplishment }\end{array}$ & \\
\hline & (8) To have romantic & \\
\hline
\end{tabular}


(9) To be free to act the way I

feel

(10) To understand more about myself

(11) To have others know that I have been there

(12) To feel inner harmony/peace

(13) To meet new and varied people

(14) To be away from daily routine

(15) To be away from interpersonal relationship (family, friends, colleague...)

(16) To Shop

(17) To have fun or be entertained

(18) To visit the cultural and heritage sites

(19) To experience culture and conventions

(20) To visit the places I have read from books

(21) To visit the places I saw on TV and/or movies 
(22) To visit the places I

learned about on social media

(23) To know more about the

political and social

environment

(24) To find a place to have a

rest

How often do you follow and Newly added

discuss travel information on

social media?

How much do you think social

Newly added

media is important for your

motivation to travel abroad?

What factors do you think

Modified from Moscardo, 2011

influence your motivation to

travel abroad? 


\section{Appendix B: Information sheet}

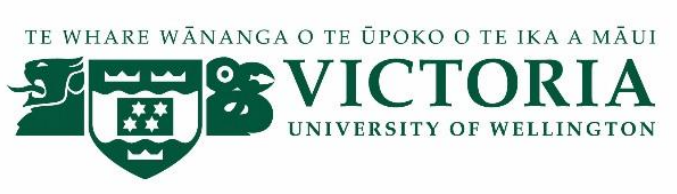

\section{The motivation of the post-90s generation for travelling abroad}

\section{INFORMATION FOR PARTICIPANTS}

You are invited to take part in this research because you belong to the post 90 -s generation in China. Please read this information before deciding whether or not to take part. If you decide to participate, thank you. If you decide not to participate, thank you for considering this request.

\section{Who am I?}

My name is Xinyue Cao and I am a Master student in management at Victoria University of Wellington, New Zealand. This research project is work towards my thesis.

\section{What is the aim of the project?}

This project aims to study the travel motives of the Chinese post-90s generation, especially motivation of travel abroad to help our understanding of this market's consumption behaviour and travel decision making. Given the significance of the Chinese post-90s generation in terms of the potential market power in the global tourism industry, this thesis aims to investigate the post-90s generation's travel motivation and influential factors. This research has been approved by the Victoria University of Wellington Human Ethics Committee [ResearchMaster application reference number: 0000026963].

\section{How can you help?}


If you agree to take part, you will complete an anonymous survey. The survey will ask you questions about your travel motivation. The survey will take you approximately 5-10 minutes to complete.

\section{What will happen to the information you give?}

This research is anonymous. This means that nobody, including the researcher will be aware of your identity. By answering it, you are giving consent for $\mathrm{u}$

$\mathrm{s}$ to use your responses in this research. Your answers will remain completely anonymous and unidentifiable. Once you submit the survey, it will be impossible to retract your answer. Please do not include any personal identifiable information in your responses.

\section{What will the project produce?}

The information from this research will be used in my Master's thesis.

\section{If you have any questions or problems, who can you contact?}

If you have any questions and you want to know about the results of this research, either now or in the future, please feel free to contact me:

\section{Student:}

Name: Sherry Cao

Email address: caoxiny@ myvuw.ac.nz

\section{Supervisor:}

Name: Dr Eerang Park

Role: Lecturer

School: Victoria University of Wellington

Email address:

eerang.park@vuw.ac.nz>@vuw.ac.nz

\section{Human Ethics Committee information}

If you have any concerns about the ethical conduct of the research you may contact the Victoria University HEC Convenor: Dr Judith Loveridge. Email hec@vuw.ac.nz or telephone +64-4-463 6028 . 


\section{0 后出国旅游的动机}

\section{参与者须知}

因为您是中国 90 后一代, 所以您被邀请参与这项研究。在决定是否参加之前, 请先阅 读这些信息。如果你决定参加, 感谢您。如果您决定不参加, 谢谢您考虑这个请求。

\section{我是谁?}

我叫曹心玥, 是新西兰惠灵顿维多利亚大学管理专业的硕士生。这个研究项目是为了 我的论文。

\section{这个项目的目的是什么?}

本项目旨在研究中国 90 后的旅游动机, 尤其是出国旅游动机, 帮助我们了解这个市场 的消费行为和旅游决策。鉴于中国 90 后对全球旅游业潜在市场力量的重要性，本文旨 在探讨中国 90 后的旅游动机和影响因素。本研究已获惠灵顿维多利亚大学人类伦理委 员会批准 [Research master 应用参考编号:0000026963]。

\section{您能给予什么帮助？}

如果您同意参加, 您将完成一项匿名调查。调查会问您关于旅行动机的一些问题。调 查大概需要 5-10 分钟完成。

\section{您提供的信息会怎样?}

这项研究是匿名的, 这意味着没有人, 包括研究人员会知道您的身份。通过回答调查 问卷, 证明您同意我们在这项研究中使用你的回答。您的回答将完全匿名, 无法辨认。 
一旦您提交了调查, 就不可能收回您的答案。请不要在您的回应中包含任何足以辨识 您身分的信息。

\section{这个项目会产生什么?}

本研究的信息将用于我的硕士论文。

\section{如果您有任何问题，您可以联系谁？}

无论是现在还是将来, 如果您有任何问题想知道这个研究的结果吧, 请随时联系我

\section{学生:}

姓名: 曹心玥

邮箱地址: caoxiny@myvuw.ac.nz

\section{导师:}

姓名: Eerang Park 博士

角色: 讲师

学校: 惠灵顿维多利亚大学

邮箱地址:

eerang.park@vuw.ac.nz>@vuw.ac.nz

\section{人类伦理委员会信息}

如果您对研究的伦理行为有任何担忧, 你可以联系维多利亚大学 HEC 召集人:Judith Loveridge 博士。电子邮件: hec@vuw.ac 或 新西兰电话+64-4-463 6028 。 


\section{Appendix C: Questionnaire}

\section{Questionnaire}

\section{Introduction}

This questionnaire asks about the travel motivations of the Chinese post-90s generation to travel abroad. It is a voluntary survey and will ensure anonymous. You do not need to reveal your name. Also, you have no obligation to participate if you do not want. Information gathered during the research will be used solely for the purpose of my Master's thesis, and all data will be stored securely on a computer with password-restricted access and only the researcher and supervisor can access the data. All answers will be aggregated in analysis and the report of this research. If you have any questions or comments, please contact with Sherry Cao by email (1533590596@qq.com) or Wechat (cxy1995727). Thank you for your support and time.

\section{Section 1. Travel experiences}

1.1 How many times per year do you travel abroad without your family?

1.2 What is the average cost of your abroad trip? ( Please circle the letter of your choice)
a. Less than 5,000 RMB
b. More than or equal to 5,000 RMB and less than 10,000 RMB
c. More than or equal to $10,000 \mathrm{RMB}$ and less than $15,000 \mathrm{RMB}$
d. More than or equal to $15,000 \mathrm{RMB}$ and less than 20,000 RMB
e. More than or equal to $20,000 \mathrm{RMB}$

1.3 How many days do you usually stay when you travel abroad?

1.4 Where do you get information about travelling abroad? ( Please circle the letter of your choice)

a. Newspaper/magazine 
b. Social media (example: Weibo, Wechat friends, Facebook, Instagram, etc.)

c. TV

d. Broadcast

e. From other's oral introductions

f. Other ways:

1.5 What kind of accommodation do you usually choose when you travel abroad? ( Please circle the letter of your choice)
a. Luxury hotel
b. Budget hotel
c. Youth hostel
d. Other:

\section{Section 2. Travel motivations}

2.1 Please indicate to what extent you agree with the following motivations to travel abroad (Where: 1 = strongly disagree, $2=$ disagree, $3=$ neutral, $4=$ agree, $5=$ strongly agree). (Please circle the only one number per question).

\begin{tabular}{lccccc}
\hline & $\begin{array}{c}\text { Strongly } \\
\text { disagree }\end{array}$ & Disagree & Neutral & Agree & $\begin{array}{c}\text { Strongly } \\
\text { agree }\end{array}$ \\
\hline $\begin{array}{l}\text { (1)To experience } \\
\text { something different }\end{array}$ & 1 & 2 & 3 & 4 & 5 \\
$\begin{array}{l}\text { (2) To experience the local } \\
\text { conditions and social }\end{array}$ & 1 & 2 & 3 & 4 & 5 \\
customs of the destination & & & & &
\end{tabular}


(3) To enjoy the natural scenery of the destination

(4) To visit places related to my personal interests

(5) To see celebrities

(6) To Feel the special atmosphere of the destination

(7) To gain a sense of accomplishment

(8) To have romantic relationships

(9) To be free to act the way I feel

(10) To understand more about myself

(11) To have others know that I have been there

(12) To feel inner harmony/peace

(13) To meet new and varied people 
(14) To be away from daily routine

(15) To be away from interpersonal relationship (family, friends,

colleague...)

(16) To Shop

(17) To have fun or be entertained

(18) To visit the cultural and heritage sites

(19) To experience culture and conventions

(20) To visit the places I have read from books

(21) To visit the places I saw on TV and/or movies

(22) To visit the places I learned about on social media

(23) To know more about the political and social 2 34 5 environment

(24) To find a place to have a rest 
(25) To release my work/study pressure 1 2 3 4 5

2.2 How often do you follow and discuss travel information on social media? (Please circle the letter of your choice)
a. Every day
b. 2-6 times a week
c. Once a week
d. Less than once a week
e. Never

2.3 How much do you think social media is important for your motivation to travel abroad? (Where: $1=$ not at all important, $2=$ of little importance, $3=$ moderately important, $4=$ important, $5=$ very important). (Please circle the only one number).

\begin{tabular}{ccccc}
\hline $\begin{array}{c}\text { Not at all } \\
\text { important }\end{array}$ & $\begin{array}{c}\text { Of little } \\
\text { importance }\end{array}$ & $\begin{array}{c}\text { Moderately } \\
\text { important }\end{array}$ & Important & $\begin{array}{c}\text { Very } \\
\text { important }\end{array}$ \\
\hline 1 & 2 & 3 & 4 & 5 \\
\hline
\end{tabular}

2.4 How much do you think education that you have received is important for your motivation to travel abroad? (Where: $1=$ not at all important, $2=$ of little importance, 3 =moderately important, 4 = important, 5 = very important). (Please circle the only one number).

\begin{tabular}{ccccc}
\hline Not at all & Of little & Moderately & Important & Very \\
important & importance & important & & important \\
\hline
\end{tabular}


2.5 How much do you think being an only child is important for your overseas travel motivation? (Where: 1 = not at all important, $2=$ of little importance, 3 =moderately important, 4 = important, 5 = very important). (Please circle the only one number).

\begin{tabular}{ccccc}
\hline $\begin{array}{c}\text { Not at all } \\
\text { important }\end{array}$ & $\begin{array}{c}\text { Of little } \\
\text { importance }\end{array}$ & $\begin{array}{c}\text { Moderately } \\
\text { important }\end{array}$ & Important & $\begin{array}{c}\text { Very } \\
\text { important }\end{array}$ \\
\hline 1 & 2 & 3 & 4 & 5 \\
\hline
\end{tabular}

2.6 What factors do you think influence your motivation to travel abroad?

\section{Section 3. Demographics}

3.1 What is your gender?
a. Male
b. Female
c. Others

3.2 What is your occupation?

3.3 Are you the only child in your family?
a. Yes
b. No 
3.4 What is your annual income?
a. Less than 30,000 RMB
b. More than or equal to $30,000 \mathrm{RMB}$ and less than $80,000 \mathrm{RMB}$
c. More than or equal to $80,000 \mathrm{RMB}$ and less than $130,000 \mathrm{RMB}$
d. More than or equal to 130,000 RMB and less than 180,000 RMB
e. More than or equal to $180,000 \mathrm{RMB}$

3.5 What is your education level?
a. Below high school
b. High school
c. Undergraduate degree
d. Master's degree
e. $\mathrm{PhD}$

3.6 What is your birthplace and current living place?

Birthplace:

Current living place: 


\section{问卷调查}

简介: 本问卷调查了中国 90 后出国旅游的动机。这是一项自愿调查, 将确保匿名, 你 不需要透露你的名字。并且, 如果你不想参加, 你也没有义务参加。在研究过程中收 集到的信息将完全用于我的硕士论文, 所有数据将安全存储在设有密码限制的计算机 上, 只有研究人员和主管才能访问这些数据。所有的答案将汇总在分析和研究报告中。 如果您有任何疑问或意见，请通过邮件联系曹心玥 (1533590596@qq.com)或微信 (cxy1995727)。感谢您的支持和时间。

\section{第 1 节旅行经历}

1.1 你平均每年进行多少次没有家人陪同的出国旅行?

1.2 你出国旅行的平均花费是多少? (请圈出你选择的字母)
a. 5000 元以下
b. 等于或多于 5000 元，小于 10,000 元
c. 等于或多于 10,000 元，小于 15,000 元
d. 等于或多于 15,000 元，小于 20,000 元
e. 大于 20,000 元

1.3 你在国外的旅行通常会进行多长时间？

1.4 你从哪里得到出国旅游的信息?(请圈出你选择的字母)
a.报纸/杂志
b. 社交媒体(如:微博、微信好友、Facebook、Instagram 等) 

c. 电视
d. 广播
e. 其他人的口头介绍
f.其他方式:

1.5 当你出国旅行时, 你通常选择什么样的住宿?(请圈出你选择的字母)
a.豪华酒店
b.经济型酒店
c. 青年旅舍
d. 其他:

\section{第 2 节 旅游动机}

2.1 请说明您在何种程度上同意以下出国旅游动机 $(1=$ 强烈不同意, $2=$ 不同意, $3=$ 中 立, 4 =同意, 5 =强烈同意)。(请每题只圈出一个数字)。

\begin{tabular}{|c|c|c|c|c|c|}
\hline & $\begin{array}{l}\text { 强烈不 } \\
\text { 同意 }\end{array}$ & 不同意 & 中立 & 同意 & $\begin{array}{c}\text { 强烈同 } \\
\text { 意 }\end{array}$ \\
\hline (1) 体验一些不同的东西 & 1 & 2 & 3 & 4 & 5 \\
\hline $\begin{array}{l}\text { (2) 体验目的地的风土人 } \\
\text { 情 }\end{array}$ & 1 & 2 & 3 & 4 & 5 \\
\hline $\begin{array}{l}\text { (3) 享受目的地的自然风 } \\
\text { 光 }\end{array}$ & 1 & 2 & 3 & 4 & 5 \\
\hline
\end{tabular}


(4) 参观与我个人兴趣有

关的地方

(5) 去见名人

（6）感受目的地的特殊氛

围

2

3

5

(7) 获得成就感

2

4

5

(8) 恋爱

(9) 自由地按照我的感觉

1

2

3

4

5 行事

(10) 了解更多关于我自 1

2

3

4 5 己的知识

(11) 让别人知道我曾经 1 2 3

4 5 到过那里

(12) 感受内心的和谐/安 1 2 3 4 5 宁 
(13) 结识各种各样的新

朋友

(14) 远离日常事务

(15) 远离人际关系(家 人、朋友、同事等)

（16）购物

(17) 娱乐

（18）参观文物古迹

(19) 体验文化与习俗

（20）去参观我从书上读 到的地方

(21) 参观我在电视和/或 电影上看到的地方

（22）参观我在社交媒体 上了解到的地方

（23）了解更多有关政治 及社会环境的资料 
(24) 找个地方休息一下

1

2

3

4

5

(25) 释放我的工作/学习

压力

1

2

3

4

5

2.2 你多久在社交媒体上关注和讨论一次旅游信息? (请圈出你选择的字母)
a. 每天
b. 每周 2-6 次
c.每周 1 次
d. 每周少于 1 次
e.从不

2.3 你认为社交媒体对你出国旅行的动机有多重要? (其中: $1=$ 完全不重要, $2=$ 不重要, $3=$ 中度重要, 4 = 重要, $5=$ 非常重要)。(请每题只圈出一个数字)。

完全不重要不重要渡重要重要非常重要

$\begin{array}{lllll}1 & 2 & 4 & 5\end{array}$

2.4 你认为你所接受的教育对你出国旅游的动机有多重要? (其中: $1=$ 完全不重要, $2=$ 不 重要, $3=$ 中度重要, 4 =重要, $5=$ =非常重要)。(请只圈出一个数字)。 
完全不重要不重要蝶重要重要非常重要

$\begin{array}{lllll}1 & 2 & 3 & 4 & 5\end{array}$

2.5 你认为在家里是独生子女与否对你出国旅行的动机有多重要? (其中:1 = 完全不重要, $2=$ 不重要, $3=$ 中度重要, $4=$ 重要, $5=$ 非常重要)。(请只圈出一个数字)。

完全不重要不重要渡重要重要非常重要

$\begin{array}{lllll}1 & 2 & 3 & 4 & 5\end{array}$

2.6 你认为哪些因素会影响你出国旅游的动机?

\section{第 3 节 个人统计}

3.1 你的性别是什么?
a. 男
b. 女
c. 其他

3.2 你的职业是什么? 


\section{3 你是家里唯一的孩子吗?}
a. 是
b. 否

3.4 你的年收入是多少?
a. 少于 30,000 万元
b. 等于或多于 30,000 元, 少于 80,000 元
c. 等于或多于 80,000 元, 少于 130,000 元
d. 等于或多于 130,000 元, 少于 180,000 元
e. 多于 180,000 元

3.5 你的教育程度是?
a. 高中以下
b. 本科学位
c. 硕士学位
d. 博士

3.6 你现在的出生地和居住地是哪里?

出生地:

居住地: 